\title{
Evaluation of Recent Advanced Soft Computing Techniques for Gully Erosion Susceptibility Mapping: A Comparative Study
}

\author{
Alireza Arabameri ${ }^{1}\left(\mathbb{D}\right.$, Thomas Blaschke ${ }^{2} \mathbb{( D}$, Biswajeet Pradhan ${ }^{3,4}(\mathbb{D}$, \\ Hamid Reza Pourghasemi ${ }^{5, *(D)}$, John P. Tiefenbacher ${ }^{6}(\mathbb{D})$ and Dieu Tien Bui ${ }^{7, *}$ \\ 1 Department of Geomorphology, Tarbiat Modares University, Tehran 36581-17994, Iran; \\ alireza.ameri91@yahoo.com \\ 2 Department of Geoinformatics_Z_GIS, University of Salzburg, 5020 Salzburg, Austria; \\ thomas.blaschke@sbg.ac.at \\ 3 Centre for Advanced Modelling and Geospatial Information Systems (CAMGIS), Faculty of Engineering and \\ IT, University of Technology Sydney, Ultimo, NSW 2007, Australia; biswajeet.pradhan@uts.edu.au \\ 4 Department of Energy and Mineral Resources Engineering, Choongmu-gwan, Sejong University, \\ 209 Neungdong-ro, Gwangjin-gu, Seoul 05006, Korea \\ 5 Department of Natural Resources and Environmental Engineering, College of Agriculture, Shiraz University, \\ Shiraz 71441-65186, Iran \\ 6 Department of Geography, Texas State University, San Marcos, TX 78666, USA; tief@txstate.edu \\ 7 Institute of Research and Development, Duy Tan University, Da Nang 550000, Vietnam \\ * Correspondence: hr.pourghasemi@shirazu.ac.ir (H.R.P.); Dieu.TienBui@gmail.com (D.T.B.)
}

Received: 27 November 2019; Accepted: 31 December 2019; Published: 7 January 2020

check for updates

\begin{abstract}
Gully erosion is a problem; therefore, it must be predicted using highly accurate predictive models to avoid losses caused by gully development and to guarantee sustainable development. This research investigates the predictive performance of seven multiple-criteria decision-making (MCDM), statistical, and machine learning (ML)-based models and their ensembles for gully erosion susceptibility mapping (GESM). A case study of the Dasjard River watershed, Iran uses a database of 306 gully head cuts and 15 conditioning factors. The database was divided 70:30 to train and verify the models. Their performance was assessed with the area under prediction rate curve (AUPRC), the area under success rate curve (AUSRC), accuracy, and kappa. Results show that slope is key to gully formation. The maximum entropy (ME) ML model has the best performance (AUSRC = 0.947 , AUPRC $=0.948$, accuracy $=0.849$ and kappa $=0.699)$. The second best is the random forest $(\mathrm{RF})$ model $(\mathrm{AUSRC}=0.965, \mathrm{AUPRC}=0.932$, accuracy $=0.812$ and kappa $=0.624)$. By contrast, the TOPSIS (Technique for Order Preference by Similarity to Ideal Solution) model was the least effective $(\mathrm{AUSRC}=0.871, \mathrm{AUPRC}=0.867$, accuracy $=0.758$ and kappa $=0.516)$. RF increased the performance of statistical index (SI) and frequency ratio (FR) statistical models. Furthermore, the combination of a generalized linear model (GLM), and functional data analysis (FDA) improved their performances. The results demonstrate that a combination of geographic information systems (GIS) with remote sensing (RS)-based ML models can successfully map gully erosion susceptibility, particularly in low-income and developing regions. This method can aid the analyses and decisions of natural resources managers and local planners to reduce damages by focusing attention and resources on areas prone to the worst and most damaging gully erosion.
\end{abstract}

Keywords: gully erosion; GIS; soft computing; hybrid model; ensemble; Iran 


\section{Introduction}

By relying on the principles of systemic view, geomorphology can help understand the mechanisms governing the natural environment. This knowledge enables humans to act in such a way that their activities will not damage the natural environment and instead complement natural processes. Nature-based solutions have been highlighted as a superior approach to land management based on engineered structures, which are still preferred by many landowners and managers [1]. To work with the landscape, geomorphologists, using their knowledge of natural morpho-dynamic factors, can predict environmental responses to prospective remedies to ensure that ecosystem services will be preserved or even restored. Before designing solutions to stop degradation and enable restoration, it is wise to understand the current state of the land.

Given the destructive effects of gully erosion (GE), solutions for managing this phenomenon to achieve sustainable development are essential [2]. Gully erosion-susceptibility mapping (GESM) is one basic method [3] to understand the mechanisms behind gully erosion. To predict the patterns of GE, a gully-erosion inventory and methods to identify and measure pertinent gully-erosion conditioning factors (GECFs) are needed [4]. Technically speaking, drainage networks, soil characteristics, rainfall, land use, topography, and lithology have been identified as the relevant GEFs controlling gully erosion and development [5].

A geographic information system (GIS), remote sensing (RS), and statistical data analyses are indispensable tools for examination of multidimensional outcomes like GE. Several factors are potential influences [3]. A variety of GIS-based approaches for GESM have been proposed and they can be classified into three types: multicriteria decision-making (MCDM), statistical modeling, and machine learning (ML) models. MCDM models are based on the knowledge of decision makers to identify, select, and weight conditioning factors [6-10]. These factors are combined to develop a GE model. Although recent developments in mathematical science, computational science, and computer technology have yielded more than 20 new MCDM models, the ranking of factors remains subjective. Statistical models provide a general advantage of working with diverse types of independent variables, like continues, binary, and categorical data [5]. The most successful models may be: information value (IV) [5], conditional probability [11], frequency ratio (FR) [12], evidential belief function [3], index of entropy (IoE) [13], certainty factor [14], weights of evidence (WOE) [15], and logistic regression [16]. The performance of statistical models is low, however. ML has proven to be efficient for GE modeling due to its ability to handle small training sets and factors with complex relationships. The most successful ML models for GE consist of multivariate adaptive regression spline [17], maximum entropy (ME) [18], boosted regression tree [19], artificial neural network (ANN) [20], random forest (RF) [21], linear discriminant analysis [22], bagging best-first decision tree [23], support vector machine [24], classification and regression trees [20], and flexible discriminant analysis [14], generalized linear model (GLM) [25], functional data analysis (FDA) [26], and the technique for order preference by similarity to the ideal solution (TOPSIS) [27].

Many ML models have been used by researchers, each has its disadvantages and advantages [22]. The selection of a suitable method is critical and requires careful consideration [24]. A comprehensive comparative assessment of MCDM, statistical, and ML models for GESM for use in arid and semi-arid regions of the world has not been conducted. This research attempts to begin to fill this gap by comparing seven models-MCDM-based TOPSIS, the statistically based statistical index (SI) and FR, and the ML-based RF, ME, GLM, and FDA—-for GESM. SI is a simple and quantitatively suitable model that has been applied to landslide-susceptibility mapping [28,29], but this is the first time it has been used for GESM.

Ensemble models, combinations of two or more statistical and ML techniques, have been proven to work for GESM [3,11]. Theoretically, ensemble models inherit the virtues and eliminate the shortcomings of individual techniques to form more robust models [30,31]. They ensure diversity to guarantee high prediction performance of their models. Ensemble models for gully-erosion modeling can be classified into simple integration models, homogeneous frameworks, and heterogeneous 
frameworks [32]. Simple integration is a simple assemblage of individual methods. A homogenous framework (i.e., boosting, bagging, rotation forest) creates subsets from the original training set, uses a ML algorithm to generate a classifier for each subset, and groups the classifiers into an ensemble model. This procedure is also used for heterogenous frameworks. The difference is that different ML algorithms are used for each of the subsets to create classifiers. Errors are dramatically reduced by combining independent learners into ensemble models [30]. This study also combines models to achieve a better collective performance to map gully-erosion susceptibility.

The study was conducted in the Dasjard River watershed, Iran. This watershed is an arid region [33] that has experienced severe GE in recent years. The aims of this study are to explore the capabilities of several individual and ensemble approaches for GESM, to evaluate the influences of GECFs on GE, and to validate the modeled susceptibility maps using several criteria. Comparison of MCDM, statistical, and ML approaches and their ensembles with a RS dataset to evaluate several GEFs for GESM is novel to this study.

\section{Description of the Study Area}

The Dasjard River watershed is found between $35^{\circ} 51^{\prime} 24^{\prime \prime}$ and $36^{\circ} 22^{\prime} 32^{\prime \prime} \mathrm{N}$ and between $55^{\circ} 29^{\prime} 54^{\prime \prime}$ and $56^{\circ} 23^{\prime} 14^{\prime \prime}$ E (Figure 1), covering $2820.29 \mathrm{~km}^{2}$. Elevation ranges from 793 to $2418 \mathrm{~m}$ above sea level (m.a.s.l.). The steepest slope in the watershed is $73^{\circ}$ and the mean is $3.8^{\circ}$. The central portion of the watershed is generally flat. In fact, $36.5 \%$ of the study area is a relatively flat plain. Precipitation ranges from $47.34 \mathrm{~mm}$ to $230.43 \mathrm{~mm}$ annually across the region, but the average is $154.3 \mathrm{~mm}$. More than $75 \%$ of the precipitation occurs in December and January [33]. The mean annual temperature is $17.8^{\circ} \mathrm{C}$ and the range is from $43{ }^{\circ} \mathrm{C}$ to $-6^{\circ} \mathrm{C}$ [33]. The climates across the watershed are arid and semiarid [33].

Reading from the 1:100,000 scale Toroud sheet from the Geological Survey Department of Iran [34], the region is covered by Quaternary lithotypes. Clayey material, well-sorted sand dunes, salt concretions, mixed terrace deposits, and swamp or marsh deposits are the most important units [34]. The geological structure of the study area is crossed by an important E-to-W Quaternary strike fault (the Toroud fault) that is responsible for uplift of a metamorphic basement in the northern part of the study area. Morphologically, steep slopes (average $>30^{\circ}$ ) dominate the northern third of the area. High local relief is a product of heavy dissection of an uplifted surface. These slopes display the rectilinear-convex profile of V-shaped valleys. The central third of the watershed has gentle slopes where Quaternary deposits are found as outcrops. Denudation from mass wasting and water erosion has significantly affected hill slopes. The profiles are well articulated with concave or convex shapes and are incised by concave valleys. The landscape of the middle of the watershed is characterized by terraces, deeply dissected by V-shaped or concave valleys. More recent fluvial terraces and alluvial fans are also commonplace. Several soil types are found in the Dasjard River watershed. The soils are poorly developed (Aridisols and Entisols) [35] and frequently appear truncated or strongly degraded at the surface by water erosion.

The gully features in the study region range from $0.79 \mathrm{~m}$ to $365 \mathrm{~m}$ in length, and are at least $0.65 \mathrm{~m}$ deep, but can be as much as $7.2 \mathrm{~m}$ deep. The widths of gullies range from $0.76 \mathrm{~m}$ to $19.4 \mathrm{~m}$. These formations reflect the primary mechanism of landscape degradation in the area, particularly soil erosion. Water erosion occurs relatively slowly over long periods of time, but even relatively small rainfall events can yield significant gully incision and retrogradation. Field monitoring of gully head cuts in the area has distinguished lateral erosion, primarily caused by instability of the perimeter edges of the incision, which leads to gravitational collapse ranging from micro- to meso-scale impacts. The main gullies have V- and U-shaped cross-sections that retrograde into steep, unstable scarps. The river valley contains gullies that formed on both river terraces and slopes. Gullying degrades agricultural land, roadways, and irrigation canals, threatening settlements and local economies.

Piping is an important process related to gully erosion. Piping dissolves soluble soil materials and disaggregates loose soil. Like sinkholes, pipes undercut structures and create tunnels. These features are most often caused by infiltration into susceptible materials and subsequent shallow groundwater 
flows. The Biarjamand watershed has extensive deposits of fine-grained (silt and clay) soils and in soils with soluble (salt, gypsum, and carbonate) mineral fractions. The former, due to their clay content, expand and contract as they moisten and desiccate. During dry seasons, the soil contracts, weakens, and cracks. During wet seasons, the cracks provide paths for infiltration and subsurface flows. The latter dissolve, chemically removing soil fractions and horizontally transporting minerals in solution with flowing water and then vertically to the surface through leaching.

Tunneling and gullying also occur in formations in low- and flat-lands that contain marls and silts. Erosion begins along gully scarps where water may stagnate and create holes from shrink and swell processes. As a hole grows, it may eventually connect to a main gully, widening and elongating it. Piping, tension-crack development, dispersion, bank collapse, and rill erosion are important mechanisms initiating and developing gullies.

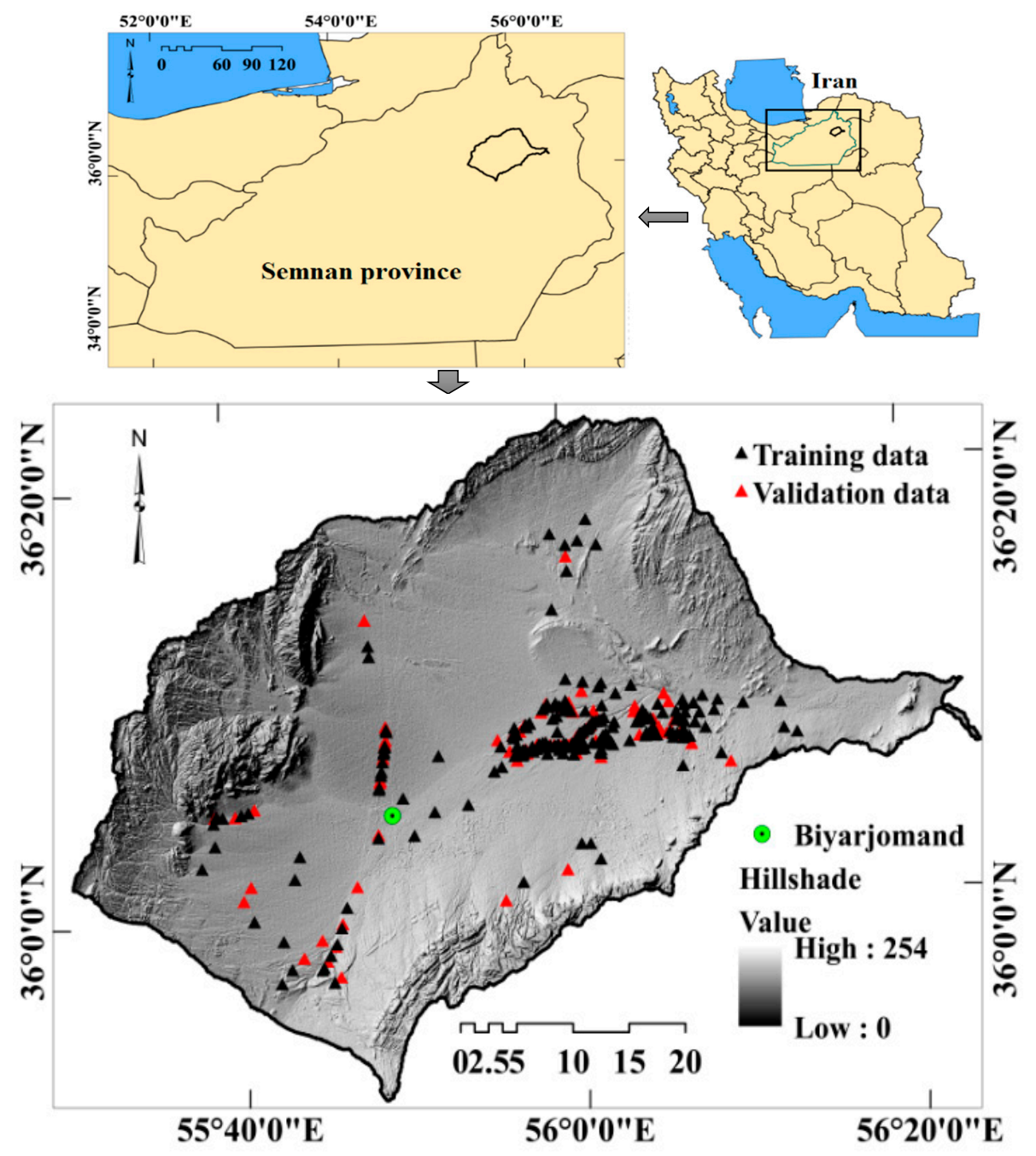

Figure 1. Location of study area in Semnan province and Iran, and location of training and validation gullies in the study area.

\section{Materials and Methods}

\subsection{Data Used}

A gully-erosion inventory map (GEIM) was developed from an extensive field survey. Three hundred and six gully erosion events were identified in the region and geolocated with a global positioning system (GPS) device (Figure 2). They were randomly divided into a training set (70\%, 213 gully locations) and a validation set (30\%, 92 gully locations). Gullies occupy $141.3 \mathrm{~km}^{2}$, comprising 
$5 \%$ of the study area. The gullies, mapped as polygons, were converted to points (locations of the head-cut portion of each gully). The point locations were used in modeling and validation. An equivalent number and percentage of non-gully point locations were randomly chosen and were used in calibration and validation procedures.

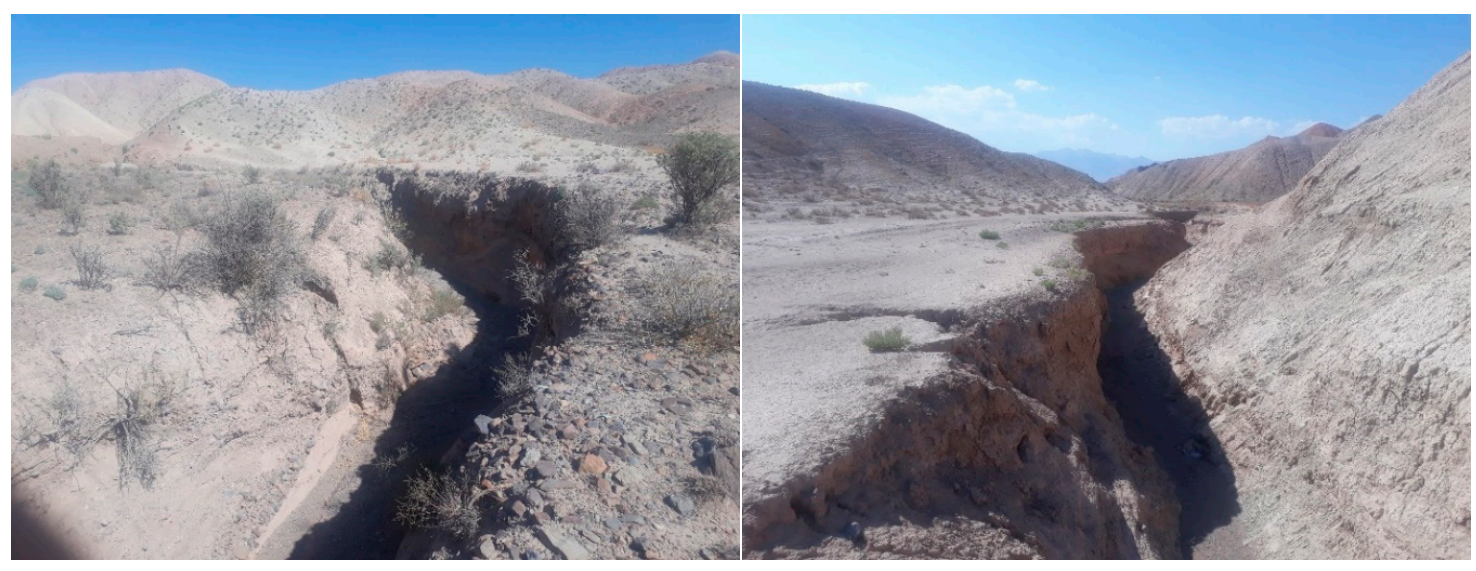

Figure 2. Sample of gullies in the study area.

The fifteen most important gully erosion conditioning factors (GECFs) were chosen based on a literature review [3,11,13-15], assessments of the physical characteristics of the study area, the scale, and availability of data, and a consideration of the intended purpose of research. These GECFs are elevation, slope, plan curvature (PC), topography wetness index (TWI), convergence index (CI), terrain ruggedness index (TRI), topography position index (TPI), distance to stream, drainage density, distance to road, normalized difference vegetation index (NDVI), rainfall, soil type, land use/land cover (LU/LC), and lithology (Table 1). An ALOS DEM with a spatial resolution of $12.5 \mathrm{~m}$, topography and geology maps with 1:50,000 (www.ngo-org.ir) and 1:100,000 (Toroud sheet) scales, LANDSAT-8 images archived by USGS (https://earthexplorer.usgs.gov/), a soil map with 1:100,000 scale, and rainfall statistics for a 30-year period (1986 to 2016) were used to prepare GECFs (Figure 3a-o).

Elevation affects vegetation and precipitation patterns. They therefore control the spatial distribution of gully erosion and the processes at work [36]. Slope affects surface runoff, soil erosion, and drainage density patterns. The steepness of the slope is also important as it enhances or attenuates the energy of erosive processes and gully erosion [37]. Plan curvature causes convergence or divergence of water flows on slopes and influences downslope flow [36]. These three parameters were extracted from the ALOS DEM.

Erosive-runoff capacity reflects transport capacity and flow velocity, and is determined by TWI. TWI is crucial for identifying areas prone to gully erosion [36]. The CI measures how flow in a cell diverges (negative $\mathrm{CI}$ values) or converges (positive $\mathrm{CI}$ values) [38]. The TRI indicates convexity and concavity of slopes which influences gully erosion [39]. The TPI compares the height of each pixel in the DEM to the average height of the pixels around it. This factor enables classification of landscapes into morphological classes. Positive and negative values indicate that a pixel is higher or lower in elevation than the pixels that surround it [40]. TWI, SPI, TRI, and TPI were calculated with Equations (1)-(4) [41,42]:

$$
\begin{gathered}
T W I=I n\left(A_{S} / \tan \beta,\right. \\
S P I=A s \times \tan \sigma, \\
T R I=\sqrt{|X|\left(m^{2}-m^{2} n^{2}\right),} \\
T P I=\frac{E_{\text {pixel }}}{\mathrm{E}_{\text {surrounding }}},
\end{gathered}
$$


where $A_{S}$ is the catchment area of the basin $\left(\mathrm{m}^{2} / \mathrm{m}\right), \beta$ is slope steepness (degrees), $x$ is the elevation of each neighbor cell to a specific cell $(0,0)(\mathrm{m})$, and max and min are the largest and smallest elevations among the nine neighboring pixels. $\mathrm{E}_{\text {pixel }}$ is the elevation of the cell, and $\mathrm{E}_{\text {surrounding }}$ is the mean elevation of the neighbor pixels.

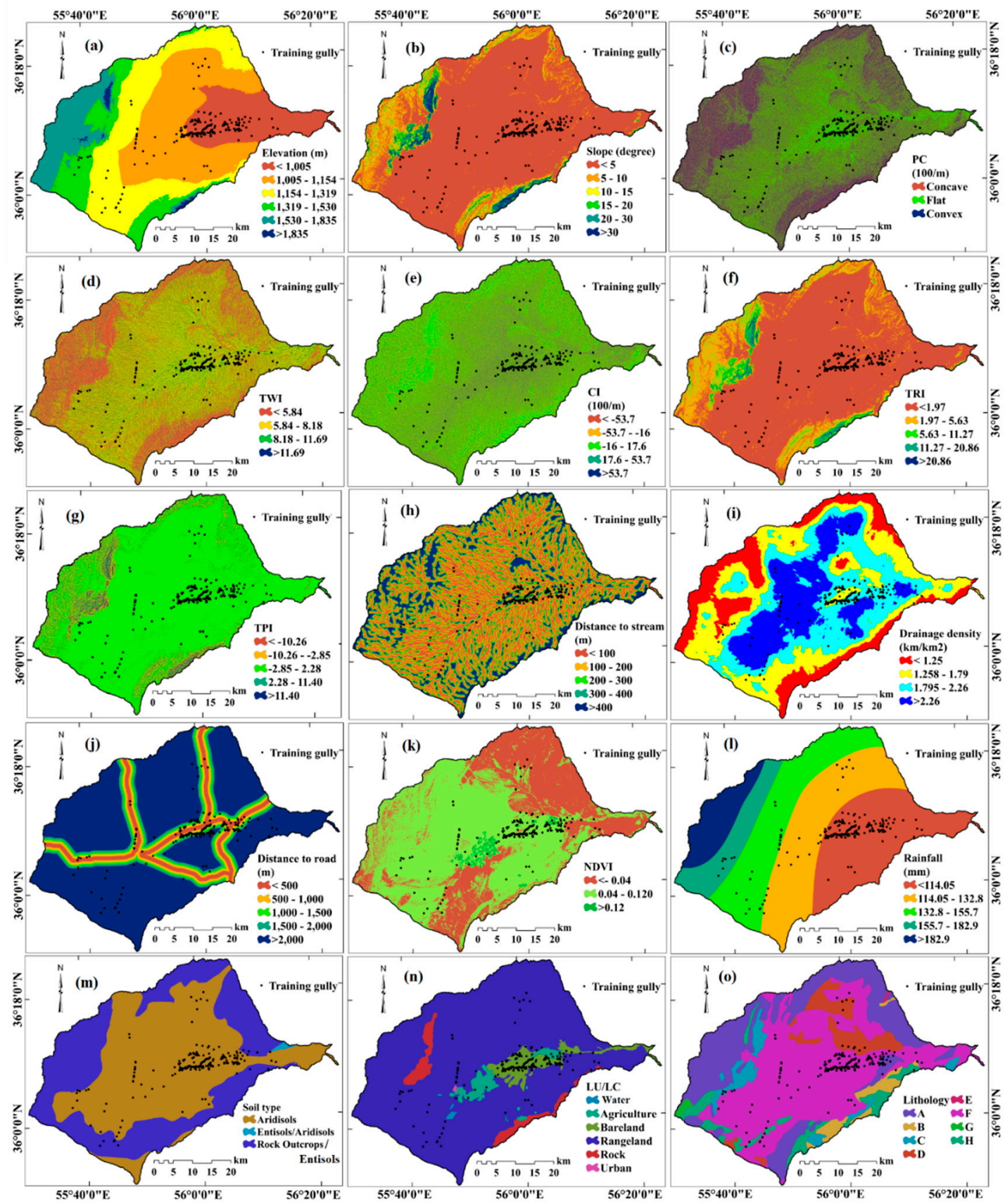

Figure 3. Gully erosion conditioning factors. (a) elevation, (b) slope, (c) plan curvature (PC), (d) topography wetness index (TWI), (e) convergence index (CI), (f) Terrain Ruggedness Index (TRI),

(g) topography position index (TPI), (h) distance to stream, (i) drainage density, (j) distance to road,

(k) Normalized Difference Vegetation Index (NDVI), (1) rainfall, (m) soil type, (n) land use/land cover (LU/LC), (o) lithology.

Gully erosion depends on the lithology of the material at or near the surface $[43,44]$. The lithology layer was prepared by digitizing a geological map (Geological Survey Department of Iran, Toroud sheet at 1:100,000 scale) [34]. Description of lithology units in the study area are shown in Table S1. 
Land use/land cover (LU/LC) impacts slope stability and gully formation. Bare lands are very prone to erosion, but land with vegetative cover has significantly less erosion [45]. An LU/LC map of the study area was produced from Landsat 8 imagery sensed on 9 August 2018. A supervised classification using the maximum likelihood algorithm was used to create the LU/LC map. The map was ground-truthed using 495 ground control points (GCP). The Kappa coefficient of the map generated is $96.23 \%$. Gullies are often linked to the drainage/stream network, and they facilitate the transport of material eroded from upland areas [36]. Higher drainage densities generate greater amounts of surface runoff [46]. To measure the parameter distance to stream and drainage density, the stream network was extracted from a PALSAR DEM in Arc Hydro. To provide more accurate flow direction and flow accumulation measures, holes in the DEM were filled, after which flow direction and accumulation were extracted. A threshold of 500 cells was used to extract the stream network. After stream extraction, the Euclidean Distance and Line Density tools in ArcGIS10.5 were used to calculate distances and densities of streams.

Roads as impenetrable surfaces disrupt natural drainage with improperly constructed culverts, by concentrating surface runoff, and by altering the hydrological functions of hillslopes. These impacts significantly increase overland flow and enable more rapid run-off, which easily erodes bare soil and causes gullying [47]. The distance to road measurements were computed from a road network layer that was extracted from a 1:50,000-scale topographic map and Google Earth images. Vegetation protects soil from many types of erosion. Vegetation can decrease the vulnerability of an area by aiding infiltration and holding soil in places with plants' roots [2]. The NDVI was computed from LANDSAT-8 data and Equation (5):

$$
N D V I=I R-R / I R+R,
$$

where $I R$ is the infrared portion of the electromagnetic spectrum and $R$ is the red portion of the electromagnetic spectrum. The layers were unified using the UTM Zone39N geographic coordinate system at a pixel size of $12.5 \mathrm{~m}$ (the DEM's spatial resolution). The classes of the GECFs are presented in Table 2.

Table 1. Classes and classification method for the various thematic data layers.

\begin{tabular}{|c|c|c|c|c|}
\hline No. & Factor & Classes & $\begin{array}{l}\text { Classification } \\
\text { Method }\end{array}$ & References \\
\hline 1 & Elevation (m) & $\begin{array}{c}\text { 1. }<1005,2.1005-1154,33.1154-1319,4.1319-1530 \text {, } \\
\text { 5. } 1530-1835,6 .>1835\end{array}$ & Natural break & [48] \\
\hline 2 & Slope $\left(^{\circ}\right)$ & 1. $<5,2.5-10,3.10-15,4.15-20,5.20-30,6 .>30$ & Manual & [49] \\
\hline 3 & Plan curvature $\left(\mathrm{m}^{-1}\right)$ & 1. Concave, 2. Flat, 3 . Convex & Manual & [48] \\
\hline 4 & TWI & 1. $<5.84,2.5 .84-8.18,3.8 .18-11.69,4 .>11.69$ & Natural break & [48] \\
\hline 5 & $\mathrm{CI}$ & $\begin{array}{c}\text { 1. }<-53.7,2 .-53.7--16,3 .-16-17.6,4.17 .6-53.7 \text {, } \\
5 .>53.7\end{array}$ & Natural break & [48] \\
\hline 6 & TRI (m) & $\begin{array}{c}\text { 1. }<1.97,2.1 .97-5.63,3.5 .63-11.27,4.11 .27-20.86 \text {, } \\
5 .>20.86\end{array}$ & Natural break & [50] \\
\hline 7 & TPI & $\begin{array}{c}\text { 1. }<-10.26,2 .-10.26--2.85,3 .-2.85-2.28,4.2 .28-11.4, \\
5 .>11.4\end{array}$ & Natural break & [50] \\
\hline 8 & Distance to river $(\mathrm{m})$ & 1. $<100,2.100-200,3.200-300,4.300-400,5 .>400$ & Manual & [48] \\
\hline 9 & $\begin{array}{l}\text { Drainage density } \\
\qquad\left(\mathrm{km} / \mathrm{km}^{2}\right)\end{array}$ & 1. $<1.25,2.1 .25-1.79,3.1 .79-2.26,4 .>2.26$ & Natural break & [51] \\
\hline 10 & Distance to road (m) & $\begin{array}{l}\text { 1. }<500,2.500-1000,3.1000-1500,4.1500-2000, \\
\text { 5. }>2000\end{array}$ & Manual & [52] \\
\hline 11 & NDVI & 1. $<-0.04,2 .-0.04-0.12,3 .>0.12$ & Natural break & [48] \\
\hline 12 & Rainfall & $\begin{array}{l}\text { 1. }<114.05,2.114 .05-132.8,3.132 .8-155.7 \\
\text { 4. } 155.7-182.9,5 .<182.9\end{array}$ & Natural break & [48] \\
\hline 13 & Soil & $\begin{array}{l}\text { 1. Rock Outcrops/Entisols, 2. Aridisols, } \\
\text { 3. Entisols/Aridisols }\end{array}$ & Soil type & \\
\hline 14 & LULC & $\begin{array}{l}\text { 1. Abkhan, 2. Agriculture, 3. Bareland, 4. Rangeland, } \\
\text { 5. Rock, 6. Urban }\end{array}$ & Land use type & \\
\hline 15 & Lithology & 1. A, 2. B, 3. C, 4. D, 5. E, 6. F, 7. G, 8. H & Lithology type & \\
\hline
\end{tabular}


Table 2. Multi-collinearity analysis among gully erosion conditioning factors.

\begin{tabular}{|c|c|c|c|c|c|c|c|}
\hline \multirow{2}{*}{ * Factors } & \multicolumn{2}{|c|}{ Unstandardized Coefficients } & \multirow{2}{*}{$\frac{\text { Standardized Coefficients }}{\text { Beta }}$} & \multirow{2}{*}{$\mathbf{t}$} & \multirow{2}{*}{ Sig. } & \multicolumn{2}{|c|}{ Collinearity Statistics } \\
\hline & B & Std. Error & & & & Tolerance & VIF \\
\hline (Constant) & -0.272 & 0.164 & & -1.666 & 0.096 & & \\
\hline lithology & -0.006 & 0.038 & -0.007 & -0.159 & 0.874 & 0.554 & 1.805 \\
\hline $\mathrm{LU} / \mathrm{LC}$ & 0.016 & 0.005 & 0.164 & 3.033 & 0.003 & 0.415 & 2.412 \\
\hline Soil type & 0.083 & 0.037 & 0.104 & 2.205 & 0.028 & 0.546 & 1.831 \\
\hline Drainage density & 0.073 & 0.029 & 0.107 & 2.517 & 0.012 & 0.672 & 1.489 \\
\hline Rainfall & 0.002 & 0.029 & 0.005 & 0.076 & 0.939 & 0.245 & 4.078 \\
\hline Slope & 0.143 & 0.110 & 0.092 & 1.296 & 0.196 & 0.241 & 4.153 \\
\hline TRI & -0.079 & 0.108 & -0.055 & -0.729 & 0.466 & 0.214 & 4.668 \\
\hline TPI & 0.048 & 0.079 & 0.027 & 0.601 & 0.548 & 0.586 & 1.706 \\
\hline TWI & -0.082 & 0.059 & -0.055 & -1.404 & 0.161 & 0.784 & 1.276 \\
\hline PC & 0.054 & 0.106 & 0.019 & 0.506 & 0.613 & 0.903 & 1.108 \\
\hline NDVI & 0.102 & 0.040 & 0.107 & 2.526 & 0.012 & 0.685 & 1.459 \\
\hline Dis to stream & 0.126 & 0.041 & 0.116 & 3.084 & 0.002 & 0.863 & 1.158 \\
\hline Dis to road & 0.080 & 0.013 & 0.263 & 6.148 & 0.000 & 0.666 & 1.501 \\
\hline elevation & 0.055 & 0.020 & 0.202 & 2.815 & 0.005 & 0.237 & 4.224 \\
\hline $\mathrm{CI}$ & -0.070 & 0.085 & -0.029 & -0.818 & 0.414 & 0.940 & 1.063 \\
\hline
\end{tabular}

* LU/LC: land use/land cover, TRI: Terrain Ruggedness Index, TPI: topography position index, TWI: topography wetness index, PC: plan curvature, NDVI: Normalized Difference Vegetation Index, CI: convergence index.

\subsection{Background of the Methods Used}

\subsubsection{Frequency Ratio (FR) and Statistical Index (SI)}

Two bivariate statistical models, FR and SI (descriptions and explanations found in [53-56]), have high potential for modeling environmental processes [53]. In these models, GECF and GEIM are considered dependent and independent variables, respectively. Each GECF thematic layer was analyzed relative to gullying to generate a weight of classes for that factor. The probability of gullying for each pixel was calculated using the algebraic sum of the weights of classes of all layers.

\subsubsection{Random Forest (RF)}

The RF model can be used to assess environmental issues and hazards [57]. This model combines several tree algorithms to generate repeated predictions of each phenomenon [58]. It can also learn complicated patterns and factor in the nonlinear relationships between explanatory and dependent variables. It can also incorporate and combine different data types because it does not assume anything about the distributions of the data. This model can incorporate thousands of input variables without deleting any. Details of RF can be found in [59]. In this study, RF analyses were conducted in R 3.3.1 using the 'Randomforest' package [60].

\subsubsection{Maximum Entropy (ME)}

ME is a prediction model guided by entropy maximization [61]. This model maximizes the probabilities without parametric assumptions about the input variables [62]. A detailed explanation of ME can be found in [63].

\subsubsection{Generalized Linear Model (GLM)}

GLM is the extension of the classic linear-regression model [64]. A detailed explanation of this model can be found in [64]. The species distribution modeling (SDM) package [65] was used to run GLM in R 3.3.3.

\subsubsection{Functional Data Analysis (FDA)}

The FDA model, suitable for observation data consisting of a series of real functions, was proposed by Ramsay and Dalzell [66]. A detailed explanation of the FDA model can be found in [67]. The FDA model was used to construct the GESM with the SDM package in R [65]. 


\subsubsection{Technique for Order Preference by Similarity to Ideal Solution (TOPSIS)}

TOPSIS was introduced by Hwang and Yoon [68]. The underlying logic of TOPSIS is to define the positive and negative ideal solutions. Details of this model are found in [69]. To prepare GESM with TOPSIS, the qualitative parameters were converted into quantitative parameters using the FR method. The parameters should have ascending or descending trends. Parameters that did not follow either of these trends were also weighted using the FR method. Once weighted, GECF values for 500 randomly selected points in the study area were extracted and input into SPSS. A decision matrix with 15 columns and 500 rows was prepared. The TOPSIS model was then applied in SPSS and the final weight of each point was determined. The GIS point layer was populated using interpolation (kriging), thus creating a GESM.

\subsubsection{Ensemble Approaches (GLM-FDA, FR-RF and SI-RF)}

The consensus is that each model has its apparent advantages and disadvantages [3]. In this study, an ensemble of five models-FR, SI, GLM, FDA and RF-were used to produce GESMs. These integrated methods eliminate several disadvantages of bivariate methods: the failure to calculate the importance of parameters and non-calculation of the spatial relationships between the feature of interest (e.g., gullying) and the parameters that affect their formation.

\subsection{Methodology}

This research consists of several main steps (Figure 4). Data collection occurred either in the library, in the field, or in the laboratory.

Step 1: Database preparation.

Step 2: Multicollinearity analysis. If collinearity occurs among the parameters, the prediction accuracy of a model will decrease [3]. Indices of tolerance (TOL) and variance inflation factor (VIF) were used to evaluate collinearity [70]. If VIF $\leq 5$ or 10 and TOL $\leq 0.1$ or 0.2 , then no collinearity exists between factors [71].

Step 3: Configuring and training the GE models.

Step 4: Performance assessment using cutoff dependence (Area under prediction rate curve [AUPRC] and area under success rate curve [AUSRC]) and cutoff independence (accuracy and kappa).

Step 5: GESM generation.

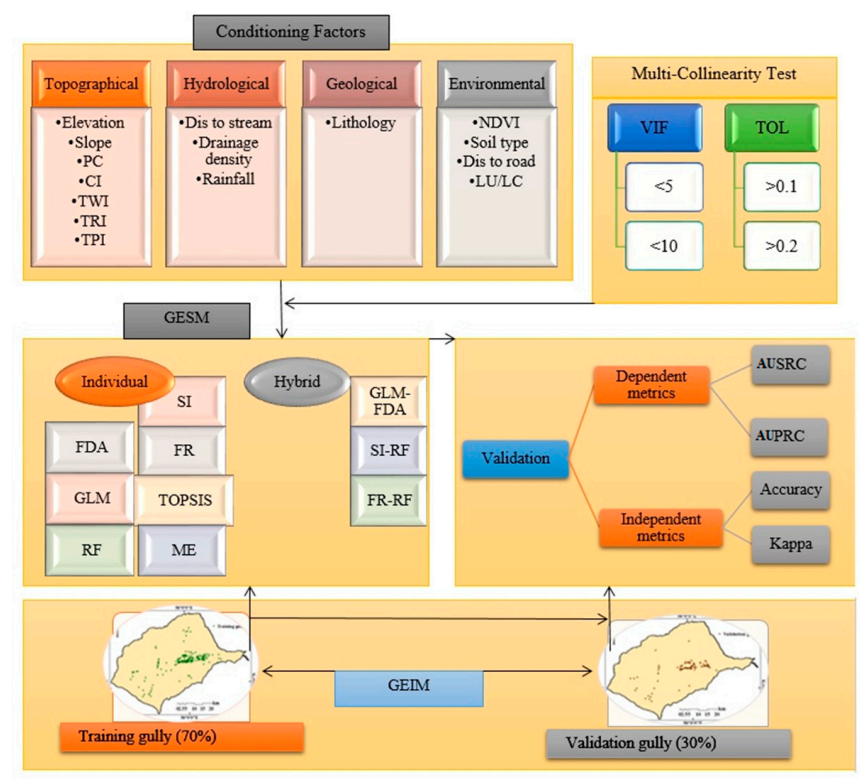

Figure 4. Flowchart of research in the study area. 


\section{Results}

\subsection{Multicollinearity Test (MT)}

The MT (Table 2) showed that no collinearity existed amongst conditioning factors. The minimum and maximum of TOL and VIF were (0.214-0.940) and (1.108-4.66), respectively. All thematic layers were used in the modeling processes.

\subsection{Spatial Relationship between Conditioning Factors and Gully Locations}

The spatial relationships between gully locations and the GECFs calculated with the FR and SI models are shown in Table 3. Elevations below $1005 \mathrm{~m}$, slopes $<5^{\circ}$, flat plan curvature, TWI $>11.69$, and CI $>53.7$ are strongly correlated with gullies. Regarding TRI $<1.09$, TPI from -2.85 to 2.28 , $<100 \mathrm{~m}$ from a stream, drainage densities ranging from 1.79 to $2.26 \mathrm{~km} / \mathrm{km}^{2}$, and places between 500 to $1000 \mathrm{~m}$ to the nearest road were the most susceptible to GE. NDVI between -0.04 and 0.12 , $<114.05 \mathrm{~mm}$ rain, aridisols, bareland (LU/LC) and Quaternary lithotypes (clayey material, well-sorted sand dunes, salt concretions, mixed terrace deposits and swamp or marsh deposits) were strongly correlated with gullies.

Table 3. Spatial relationship between conditioning factors and gully locations using frequency ratio and statistical index.

\begin{tabular}{|c|c|c|c|c|c|c|c|}
\hline \multirow{2}{*}{ * Factor } & \multirow{2}{*}{ Class } & \multicolumn{2}{|c|}{ Pixels in Domain } & \multicolumn{2}{|c|}{ Gullies } & \multirow[t]{2}{*}{ FR } & \multirow[t]{2}{*}{ SI } \\
\hline & & No & $\%$ & No & $\%$ & & \\
\hline \multirow{6}{*}{ Elevation (m) } & $<1005$ & 409583 & 16.47 & 143 & 67.45 & 4.09 & 1.41 \\
\hline & $1005-1154$ & 778,768 & 31.32 & 45 & 21.23 & 0.68 & -0.39 \\
\hline & 1154-1319 & 675,092 & 27.15 & 17 & 8.02 & 0.30 & -1.22 \\
\hline & 1319-1530 & 314,348 & 12.64 & 7 & 3.30 & 0.26 & -1.34 \\
\hline & $1530-1835$ & 290,378 & 11.68 & 0 & 0.00 & 0.00 & None \\
\hline & $>1835$ & 18,056 & 0.73 & 0 & 0.00 & 0.00 & None \\
\hline \multirow{6}{*}{ Slope $\left(^{\circ}\right)$} & $<5$ & $2,018,483$ & 81.19 & 205 & 96.70 & 1.19 & 0.17 \\
\hline & $5-10$ & 235,497 & 9.47 & 7 & 3.30 & 0.35 & -1.05 \\
\hline & $10-15$ & 98,979 & 3.98 & 0 & 0.00 & 0.00 & None \\
\hline & $15-20$ & 46,006 & 1.85 & 0 & 0.00 & 0.00 & None \\
\hline & $20-30$ & 44,839 & 1.80 & 0 & 0.00 & 0.00 & None \\
\hline & $>30$ & 42,421 & 1.71 & 0 & 0.00 & 0.00 & None \\
\hline \multirow{3}{*}{ PC (100/m) } & Concave & 792,994 & 31.90 & 55 & 25.94 & 0.81 & -0.21 \\
\hline & Flat & 907,578 & 36.50 & 94 & 44.34 & 1.21 & 0.19 \\
\hline & Convex & 785,652 & 31.60 & 63 & 29.72 & 0.94 & -0.06 \\
\hline \multirow{4}{*}{ TWI } & $<5.84$ & 805,518 & 32.40 & 33 & 15.57 & 0.48 & -0.73 \\
\hline & $5.84-8.18$ & $1,120,812$ & 45.08 & 123 & 58.02 & 1.29 & 0.25 \\
\hline & $8.18-11.69$ & 408,848 & 16.44 & 38 & 17.92 & 1.09 & 0.09 \\
\hline & $>11.69$ & 151,046 & 6.08 & 18 & 8.49 & 1.40 & 0.33 \\
\hline \multirow{5}{*}{ CI (100/m) } & $<-53.7$ & 170,770 & 6.98 & 16 & 7.55 & 1.08 & 0.08 \\
\hline & $-53.7--16$ & 614,268 & 25.10 & 44 & 20.75 & 0.83 & -0.19 \\
\hline & $-16-17.6$ & 994,363 & 40.63 & 83 & 39.15 & 0.96 & -0.04 \\
\hline & $17.6-53.7$ & 535,208 & 21.87 & 54 & 25.47 & 1.16 & 0.15 \\
\hline & $>53.7$ & 133,049 & 5.44 & 15 & 7.08 & 1.30 & 0.26 \\
\hline \multirow{5}{*}{ TRI } & $<1.97$ & $1,995,829$ & 80.28 & 207 & 97.64 & 1.22 & 0.20 \\
\hline & $1.97-5.63$ & 314,118 & 12.63 & 5 & 2.36 & 0.19 & -1.68 \\
\hline & $5.63-11.27$ & 120,287 & 4.84 & 0 & 0.00 & 0.00 & None \\
\hline & $11.27-20.86$ & 45,815 & 1.84 & 0 & 0.00 & 0.00 & None \\
\hline & $>20.86$ & 10,176 & 0.41 & 0 & 0.00 & 0.00 & None \\
\hline
\end{tabular}


Table 3. Cont.

\begin{tabular}{|c|c|c|c|c|c|c|c|}
\hline \multirow{2}{*}{ * Factor } & \multirow{2}{*}{ Class } & \multicolumn{2}{|c|}{ Pixels in Domain } & \multicolumn{2}{|c|}{ Gullies } & \multirow[t]{2}{*}{ FR } & \multirow[t]{2}{*}{ SI } \\
\hline & & No & $\%$ & No & $\%$ & & \\
\hline \multirow{5}{*}{ TPI } & $<-10.26$ & 27,479 & 1.11 & 0 & 0.00 & 0.00 & None \\
\hline & $-10.26--2.85$ & 202,970 & 8.16 & 5 & 2.36 & 0.29 & -1.24 \\
\hline & $-2.85-2.28$ & $2,103,205$ & 84.59 & 207 & 97.64 & 1.15 & 0.14 \\
\hline & $2.28-11.4$ & 130,891 & 5.26 & 0 & 0.00 & 0.00 & None \\
\hline & $>11.4$ & 21,679 & 0.87 & 0 & 0.00 & 0.00 & None \\
\hline \multirow{5}{*}{ Dis to stream $(m)$} & $<100$ & 881,433 & 35.45 & 117 & 55.19 & 1.56 & 0.44 \\
\hline & $100-200$ & 625,868 & 25.17 & 54 & 25.47 & 1.01 & 0.01 \\
\hline & $200-300$ & 443,260 & 17.83 & 25 & 11.79 & 0.66 & -0.41 \\
\hline & $300-400$ & 224,458 & 9.03 & 10 & 4.72 & 0.52 & -0.65 \\
\hline & $>400$ & 311,205 & 12.52 & 6 & 2.83 & 0.23 & -1.49 \\
\hline \multirow{4}{*}{$\begin{array}{l}\text { Drainage density } \\
\qquad\left(\mathrm{km} / \mathrm{km}^{2}\right)\end{array}$} & $<1.25$ & 461689 & 18.57 & 2 & 0.94 & 0.05 & -2.98 \\
\hline & $1.25-1.79$ & 746549 & 30.03 & 55 & 25.94 & 0.86 & -0.15 \\
\hline & $1.79-2.26$ & 712235 & 28.65 & 124 & 58.49 & 2.04 & 0.71 \\
\hline & $>2.26$ & 565752 & 22.76 & 31 & 14.62 & 0.64 & -0.44 \\
\hline \multirow{5}{*}{ Dis to road $(\mathrm{m})$} & $<500$ & 177023 & 7.12 & 32 & 15.09 & 2.12 & 0.75 \\
\hline & 500-1000 & 168791 & 6.79 & 68 & 32.08 & 4.72 & 1.55 \\
\hline & $1000-1500$ & 159125 & 6.40 & 31 & 14.62 & 2.28 & 0.83 \\
\hline & $1500-2000$ & 151080 & 6.08 & 26 & 12.26 & 2.02 & 0.70 \\
\hline & $>2000$ & 1830206 & 73.61 & 55 & 25.94 & 0.35 & -1.04 \\
\hline \multirow{3}{*}{ NDVI } & $<-0.04$ & 918021 & 36.92 & 17 & 8.02 & 0.22 & -1.53 \\
\hline & $-0.04-0.12$ & 1541694 & 62.01 & 192 & 90.57 & 1.46 & 0.38 \\
\hline & $>0.12$ & 26510 & 1.07 & 3 & 1.42 & 1.33 & 0.28 \\
\hline \multirow{5}{*}{ Rainfall (mm) } & $<114.05$ & 688309 & 27.68 & 161 & 75.94 & 2.74 & 1.01 \\
\hline & $114.05-132.8$ & 694011 & 27.91 & 21 & 9.91 & 0.35 & -1.04 \\
\hline & $132.8-155.7$ & 619724 & 24.93 & 23 & 10.85 & 0.44 & -0.83 \\
\hline & $155.7-182.9$ & 259107 & 10.42 & 7 & 3.30 & 0.32 & -1.15 \\
\hline & $<182.9$ & 225074 & 9.05 & 0 & 0.00 & 0.00 & None \\
\hline \multirow{3}{*}{ Soil type } & \multicolumn{2}{|c|}{$\begin{array}{l}\text { Rock } \\
\text { Outcrops/Entisols }\end{array}$} & 41.64 & 12 & 5.66 & 0.14 & -2.00 \\
\hline & Aridisols & 1443591 & 58.06 & 199 & 93.87 & 1.62 & 0.48 \\
\hline & \multicolumn{2}{|c|}{ Entisols/Aridisols7464 } & 0.30 & 1 & 0.47 & 1.57 & 0.45 \\
\hline \multirow{6}{*}{ LU/LC } & Abkhan & 5419 & 0.22 & 0 & 0.00 & 0.00 & None \\
\hline & Agriculture & 73837 & 2.97 & 11 & 5.19 & 1.75 & 0.56 \\
\hline & Bareland & 124293 & 5.00 & 124 & 58.49 & 11.70 & 2.46 \\
\hline & Rangeland & 2182822 & 87.80 & 76 & 35.85 & 0.41 & -0.90 \\
\hline & Rock & 98132 & 3.95 & 1 & 0.47 & 0.12 & -2.12 \\
\hline & Urban & 1722 & 0.07 & 0 & 0.00 & 0.00 & None \\
\hline \multirow{8}{*}{ Lithology } & $\mathrm{A}$ & 697041 & 28.04 & 20 & 9.43 & 0.34 & -1.09 \\
\hline & B & 79375 & 3.19 & 1 & 0.47 & 0.15 & -1.91 \\
\hline & $\mathrm{C}$ & 114582 & 4.61 & 3 & 1.42 & 0.31 & -1.18 \\
\hline & $\mathrm{D}$ & 190539 & 7.66 & 10 & 4.72 & 0.62 & -0.49 \\
\hline & $\mathrm{E}$ & 2747 & 0.11 & 0 & 0.00 & 0.00 & None \\
\hline & $\mathrm{F}$ & 153705 & 6.18 & 4 & 1.89 & 0.31 & -1.19 \\
\hline & $\mathrm{G}$ & 1236071 & 49.72 & 174 & 82.08 & 1.65 & 0.50 \\
\hline & $\mathrm{H}$ & 12165 & 0.49 & 0 & 0.00 & 0.00 & None \\
\hline
\end{tabular}

* LU/LC: land use/land cover, TRI: Terrain Ruggedness Index, TPI: topography position index, TWI: topography wetness index, PC: plan curvature, NDVI: Normalized Difference Vegetation Index, CI: convergence index.

\subsection{Relative Importance of Conditioning Factors Using the RF Model}

The relative importance of conditioning factors was determined using the RF model (Figure 5). Slope (21.46), TPI (17.96), and elevation (16.89) were keys to GE in the study area. By contrast, 
NDVI, convergence index, and drainage density are least important determinants of gully formation. The distance to stream, soil type, LU/LC, lithology, distance to road, rainfall, TRI, plan curvature, and TWI rank from 4th to 12 th, respectively.

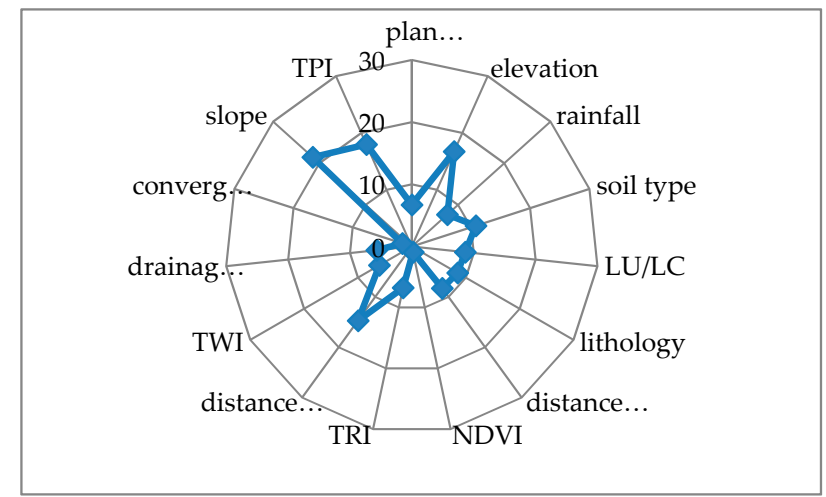

Figure 5. Relative importance of gully erosion conditioning factors using the random forest model.

\subsection{Gully Erosion Susceptibility Mapping (GESM)}

The minimum and maximum values (Table 4) of the GESMs (Figure 6a-j) produced with the 10 models are diverse. The proportions of the study area classified into the five susceptibility classes by each model (Figure 7) display significantly different results, with SI-RF and SI generating the most widespread classification of land into high or very high susceptibility and ME classifying the greatest percentage of the area as low or very low.

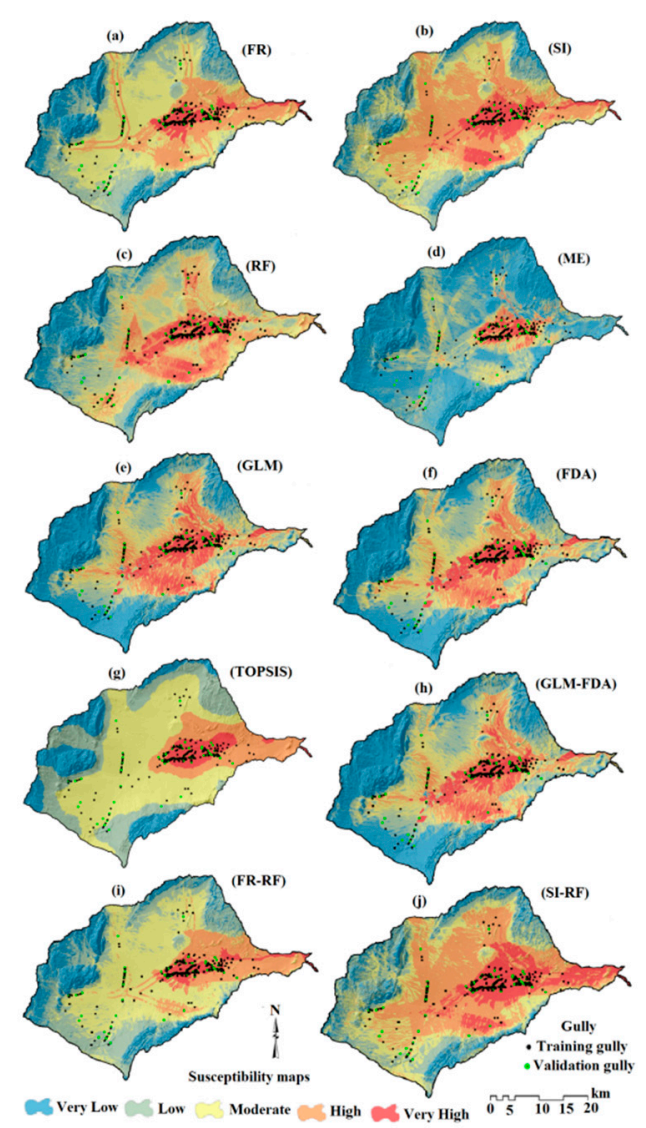

Figure 6. Gully erosion susceptibility maps. (a) frequency ration (FR), (b) statistical index (SI), (c) random forest (RF), (d) maximum entropy (ME), (e) generalized linear model (GLM), (f) functional data analysis (FDA), (g) TOPSIS, (h) GLM-FDA, (i) FR-RF, (j) SI-RF. 


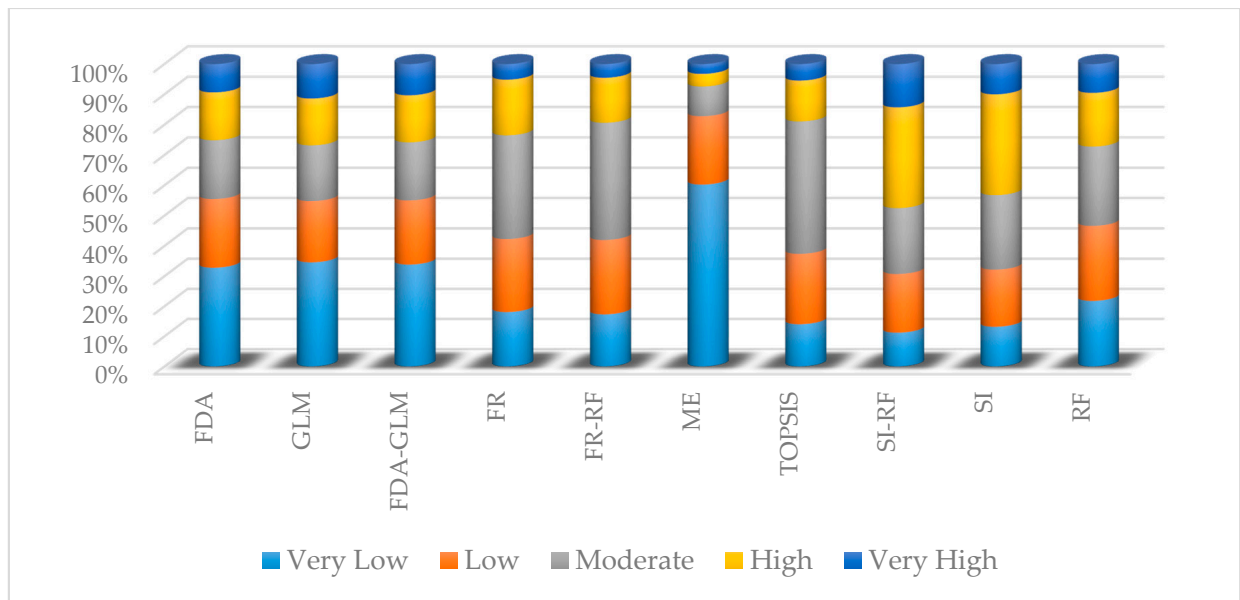

Figure 7. Percentage of each susceptibility classes in individual and hybrid models.

Table 4. Values of resulted gully erosion maps using ten models.

\begin{tabular}{cccccc}
\hline \multirow{2}{*}{ * Models } & \multicolumn{5}{c}{ Classification with a Natural Break Model } \\
\cline { 2 - 6 } & Very Low & Low & Moderate & High & Very High \\
\hline FR & $3.66-9.63$ & $9.63-13.79$ & $13.79-17.96$ & $17.96-26.57$ & $26.57-39.06$ \\
SI & $-19.3--10.5$ & $-10.5--6$ & $-6--2.27$ & $-2.27-2.25$ & $2.25-10.25$ \\
RF & $0.01-0.21$ & $0.21-0.37$ & $0.37-0.53$ & $0.53-0.72$ & $0.72-1$ \\
ME & $0.00-0.06$ & $0.06-0.17$ & $0.17-0.34$ & $0.34-0.57$ & $0.57-0.97$ \\
GLM & $0.00-0.12$ & $0.12-0.3$ & $0.3-0.49$ & $0.49-0.69$ & $0.69-0.98$ \\
FDA & $0.00-0.13$ & $0.13-0.31$ & $0.31-0.51$ & $0.51-0.73$ & $0.73-0.99$ \\
TOPSIS & $0.15-0.29$ & $0.29-0.38$ & $0.38-0.48$ & $0.48-0.61$ & $0.61-0.78$ \\
GLM-FDA & $0.00-0.13$ & $0.13-0.31$ & $0.31-0.5$ & $0.5-0.71$ & $0.71-0.99$ \\
FR-RF & $21.72-84.7$ & $84.7-131.2$ & $131.2-183.2$ & $183.2-268.1$ & $268.1-370.8$ \\
SI-RF & $-190--99.9$ & $-99.9--59.3$ & $-59.3--23.2$ & $-23.2-18.4$ & $18.4-97.4$ \\
\hline
\end{tabular}

* FR: frequency ratio, SI: statistical index, RF: random forest, ME: maximum entropy, GLM: generalized linear model, FDA: functional data analysis, TOPSIS: Technique for order preference by similarity to ideal solution.

\subsection{Validation of Results}

Validation employed AUSRC (Figure 8) and revealed the RF model (AUSRC $=0.965)($ Table 5) performed best, whereas considering AUPRC, accuracy, and kappa criteria, the ME model (AUPRC $=0.948$, accuracy $=0.849$ and kappa $=0.699)$ performed best, followed by RF (Table 5 and Figure 9 ). Results indicate that combining the RF model with FR and SI models increased the performances of the latter compared to them as stand-alone models.
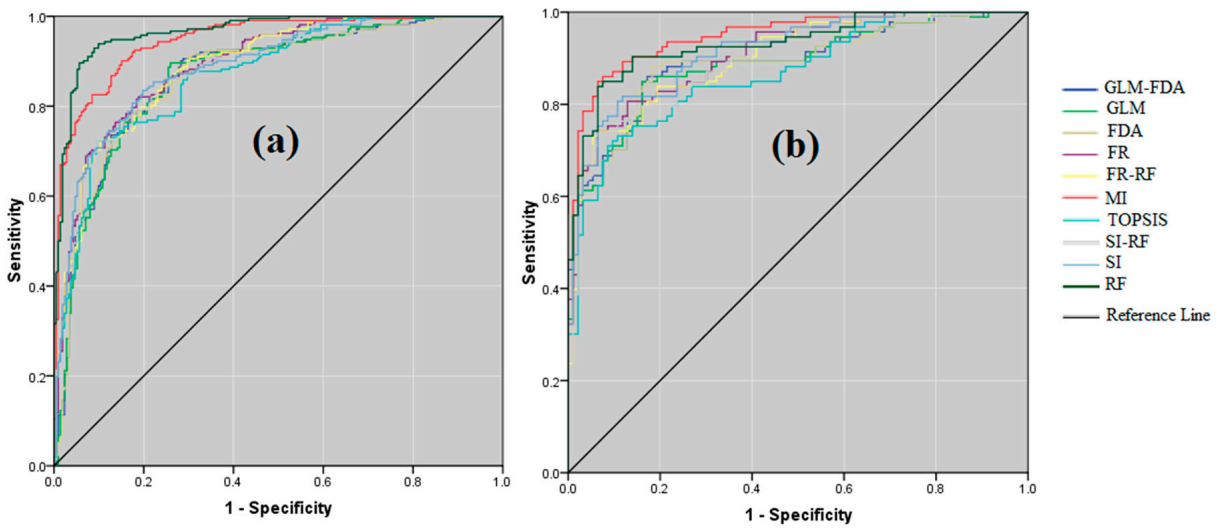

Figure 8. Area under curve in individual and ensemble models. (a) training data (success rate curve), (b) validation data (prediction rate curve). 
Table 5. Validation of gully erosion susceptibility maps using cutoff-dependent and independent criteria.

\begin{tabular}{|c|c|c|c|c|c|c|c|c|c|c|c|}
\hline \multirow[b]{2}{*}{ * Models } & \multirow[t]{2}{*}{ TN } & \multirow[t]{2}{*}{ FP } & \multirow[t]{2}{*}{ FN } & \multirow[t]{2}{*}{ TP } & \multirow[t]{2}{*}{ TPR } & \multirow[t]{2}{*}{ TNR } & \multirow[t]{2}{*}{ FPR } & \multicolumn{2}{|c|}{$\begin{array}{l}\text { Cutoff-Dependent } \\
\text { Criteria }\end{array}$} & \multicolumn{2}{|c|}{$\begin{array}{c}\text { Cutoff Independent } \\
\text { Criteria }\end{array}$} \\
\hline & & & & & & & & AUSRC & AUPRC & Aaccuracy & Kappa \\
\hline FR & 71 & 22 & 22 & 71 & 0.76 & 0.76 & 0.23 & 0.890 & 0.900 & 0.763 & 0.527 \\
\hline SI & 73 & 20 & 22 & 71 & 0.76 & 0.78 & 0.21 & 0.884 & 0.897 & 0.774 & 0.548 \\
\hline RF & 76 & 17 & 18 & 75 & 0.80 & 0.81 & 0.18 & 0.965 & 0.932 & 0.812 & 0.624 \\
\hline ME & 79 & 14 & 14 & 79 & 0.84 & 0.84 & 0.15 & 0.947 & 0.948 & 0.849 & 0.699 \\
\hline GLM & 74 & 19 & 18 & 75 & 0.80 & 0.79 & 0.20 & 0.869 & 0.887 & 0.801 & 0.602 \\
\hline FDA & 74 & 19 & 21 & 72 & 0.77 & 0.79 & 0.20 & 0.868 & 0.894 & 0.785 & 0.570 \\
\hline TOPSIS & 71 & 22 & 23 & 70 & 0.75 & 0.76 & 0.23 & 0.871 & 0.867 & 0.758 & 0.516 \\
\hline GLM-FDA & 75 & 18 & 20 & 73 & 0.78 & 0.80 & 0.19 & 0.870 & 0.891 & 0.796 & 0.591 \\
\hline FR-RF & 73 & 20 & 21 & 72 & 0.77 & 0.78 & 0.21 & 0.893 & 0.908 & 0.780 & 0.559 \\
\hline SI-RF & 71 & 22 & 21 & 72 & 0.77 & 0.76 & 0.237 & 0.889 & 0.914 & 0.769 & 0.538 \\
\hline
\end{tabular}

* FR: frequency ratio, SI: statistical index, RF: random forest, ME: maximum entropy, GLM: generalised linear model, FDA: functional data analysis, TOPSIS: Technique for order preference by similarity to ideal solution; * TN: true negative, FP: false positive, TP: true positive, FN: false negative, TNR: true negative rate, FPR: false positive rate, AUSRC: area under success rate curve, AUPRC: area under prediction rate curve.
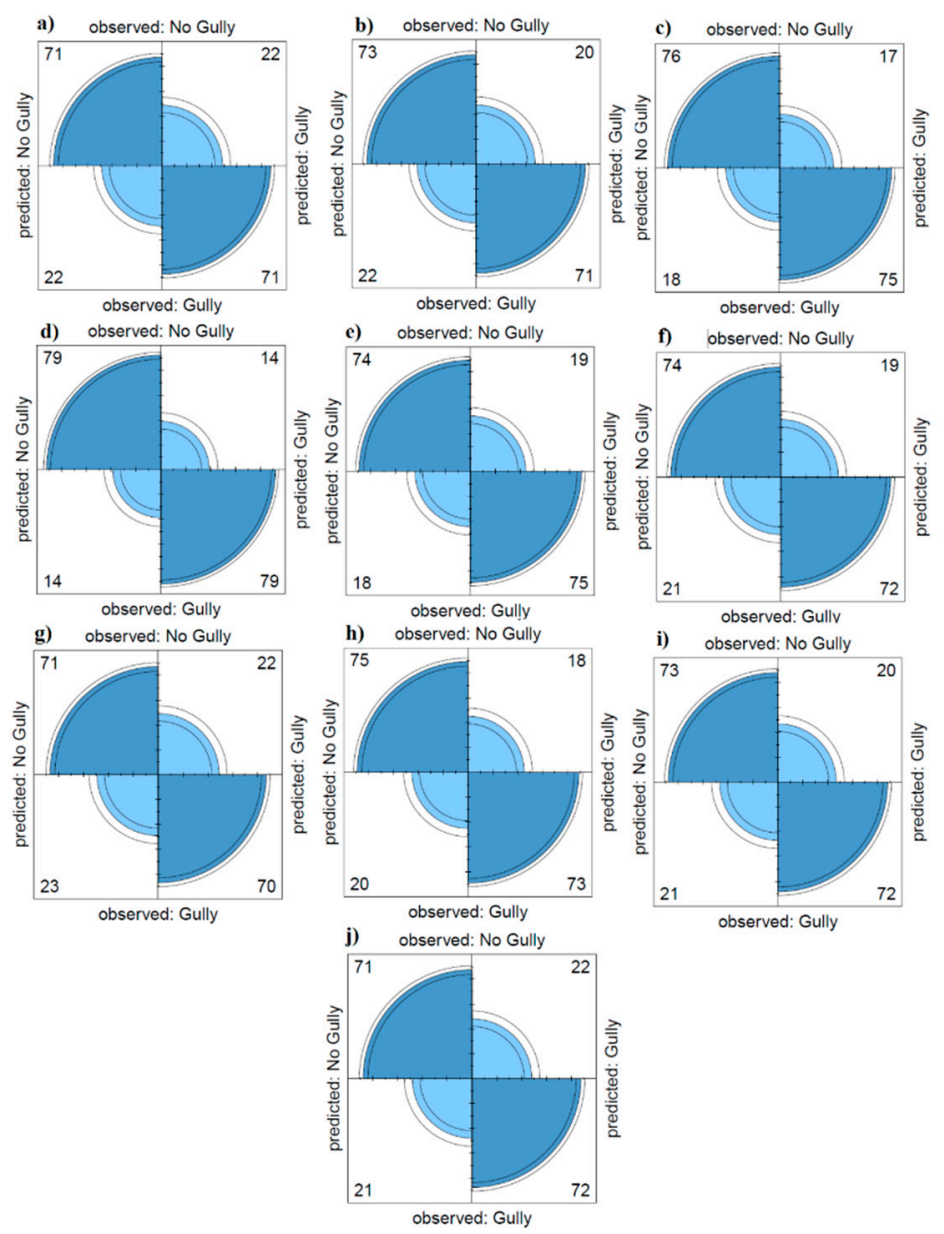

Figure 9. Values of true negative (TN), false positive (FP), true positive (TP) and false negative (FN) for each individual or ensemble model. (a) FR, (b) SI, (c) RF, (d) ME, (e) GLM, (f) FDA, (g) TOPSIS, (h) GLM-FDA, (i) FR-RF, (j) SI-RF.

\section{Discussion}

In this study, 10 GIS-based statistical, machine-learning, and multicriteria models were integrated with RS data to generate GESMs. The statistical models FR and SI were included because of their simplicity and high efficiency, and to ease of interpretation of the results [72-74]. The TOPSIS method 
was used because it requires only simple calculations and minimal computation time, has the capacity to rank the alternatives, uses both quantitative and qualitative criteria, and can determine the relative importance of alternatives and compliance with the conditions. The TOPSIS method, being local and experimental, is known as one of the best methods for decision making [75]. It is well suited for several scenarios and criteria [67,75]. The RF, MI, FDA, and GLM models were included because of their capacities to predict environmental phenomena $[63,66]$. In cases in which key data are missing, the FDA model is more efficient than traditional methods. The GLM method solves nonlinear and multiclass problems well [63]. Any of the models in this set of selected models could produce a reliable GESM.

Assessments of the spatial relationships between the GECFs and the gullies show that gullies formed mainly in areas below $1005 \mathrm{~m}$ elevation and on slopes angles less than $5^{\circ}$. Topography affects vegetation types, drainage area, geomorphological processes, weathering, soil moisture, drainage density, soil types, and precipitation. All these directly or indirectly influence GE potential [17,76,77]. Areas with gentle slopes have a high potential for accumulation of overland flows that can initiate gullying [78]. Surface and subsurface water are also key factors for gullying [79]. In both circumstances (above and below ground), the slope is the main factor initiating gully formation [80].

Flat topography is highly correlated with susceptibility to GE. This agrees with the findings of [51]. High TWI is strongly correlated with gullies in the study area. Arabameri et al. [72] used an integrated model to predict GE in the Mahabia watershed and also stated that areas with high TWI also had high positive susceptibility. Drainage density is highly correlated with susceptibility to GE, confirming the findings of $[19,81,82]$. Proximity to rivers and roads was positively correlated to gullies, as was reported by $[11,83,84]$. Natural drainage patterns are often disrupted by poorly located or poorly constructed culverts placed during road construction. Subsequently, soil is easily eroded by concentrated runoff created by impervious surfaces [85].

NDVI analysis reveals that areas with more vegetation growth had fewer gullies; areas with less vegetation had higher frequency of gully formation. This finding corroborates the results of $[5,11]$. Vegetation greatly reduces runoff and limits erosion by increasing infiltration and by protecting soil with root growth [86,87]. Aridisols are highly susceptible to GE in this region, and this agrees with [88].

Land use underpins geomorphological and hydrological processes by affecting runoff generation, sediment dynamics, and overland flows [89]. LU/LC analysis showed that agricultural and bare landscapes, where soil is often disturbed, where surface water is often concentrated [90-93], and where the surface is often unprotected by vegetation [88], had the highest susceptibility to GE in our study region. Because GE depends on the lithology of materials at or just below the surface [5] the spatial patterns of sediment origins were evaluated. Quaternary lithotypes in the study area have the highest susceptibility to GE, which is coincident with the findings of [88]. Gullying is a natural phenomenon that depends on the thresholds of several conditioning factors (e.g., rainfall, topography, flow hydraulics, pedology and land use). It is more likely to occur at locations where thresholds have been exceeded [94].

Examination of the relative importance of GECFs shows that slope, TPI, and elevation were the most important in the study area and corroborates [11-13,23]. Zabihi et al. [13] tested three models (FR, WoE and IoE) to model GE in Iran and found that of 12 GECFs, elevation and LU/LC were the most important in their study area. Meliho et al. [12] used IV and FR for GESM in the Ourika watershed in Morocco, and they found that LU/LC and slope had the most influence on gully formation.

The GESMs were classified into five different gully-erosion susceptibility classes (very low to very high) using four classification methods: geometrical interval, quantile, equal interval, and natural breaks. Comparing the results of each classification method with the high and very high gully-erosion susceptibility classes, it is clear that the natural break method provides the most accurate classification scheme. This agrees with the findings of [3].

The validation results using cutoff-dependent (AUPRC and AUSRC) and cutoff-independent (accuracy and kappa) criteria shows that ML models outperform statistical and MCDM-based models [19,70,88,95]. ML models are advantageous because they do not require a strict set of 
assumptions as is the case with many statistical methods [22]. ML models also use algorithms to discern the relationships between GECFs and gullies and therefore do not rely on a structural model [19]. These models also benefit from iterative learning algorithms which help them learn and improve [19].

AUSRC shows that RF had the best performance among the 10 models. This confirms the findings of $[88,96]$. Arabameri et al. [88] used three data-mining models for gully-erosion assessment in the Shahroud watershed in northeastern Iran, and found that RF performed best. When there is considerable noise in data, this method is less sensitive to ANNs and can better assess factors compared with others $[97,98]$. The most important advantages of RF models are their capacities to learn nonlinear relationships, that they have high predictive accuracy, they are able to determine relative factor importance, they can deal with distorted data, and they have high categorization ability.

Based on the AUPRC, accuracy, and kappa results, ME was shown to have the best overall performance. This reflects similar findings in [98-101]. ME exceeds other ML models because it uses search-based optimization to determine the relative importance of factors [101]. Results of the ensemble RF-FR and RF-SI statistical models reveal that RF is one of the best classification algorithms to use to considerably improve the performance of single classifiers [102,103]. Moreover, RF can decrease the dependence of statistical models on the relationships among the conditioning factors [30].

\section{Conclusions}

GE is a bane of rural sectors in arid and semi-arid regions of the world. To combat the formation of gullies, it is often necessary to diagnose the scope of the problem and the causes endemic to the local environment. GESM is a key tool for sustainable management and use of soil and water resources. The foundation of GESM is the spatial predictive model. There is no consensus among scholars about the best modeling approach (statistical, ML, or MCDM) to generate an accurate spatial assessment of GE. There are constant technological advancements that make data available for incorporation and analysis in ways that are more efficient and economical. These conditions are very important in regions that are more remote or that have fewer financial resources. This study attempted to tackle this question by comparing ten individual and ensemble models-FR, SI, RF, ME, FDA, GLM, TOPSIS, SI-RF, FR-RF and GLM-FDA-from among the extant statistical, ML, and MCDM approaches to model gully-erosion susceptibility in the Dasjard River watershed, Iran. RS data and GIS techniques were used to compile and analyze 15 environmental, geological, geomorphological, and anthropogenic GECFs that were selected according to the MT. VIF and TOL indicate that there is no multicollinearity among them. The results show that the RF ML model performed the best according to the AUROC. In this model, slope, TPI, and elevation were the key factors generating gullying in the study area. The RF model combines several tree algorithms to iteratively predict a phenomenon. RF can learn complicated patterns and can consider nonlinear relationships between dependent and independent variables. Furthermore, it can integrate data of different types, requires no assumptions about the normality of the data used, and can incorporate thousands of variables without discarding any of them. Based on the AUSRC, AUPRC, accuracy, and kappa values, ME outperformed even RF. Validation tests indicate that RF and ME, which are both ML models, outperformed all statistical and MCDM models tested. Ensemble models, particularly the combinations of RF with FR and SI, improved the prediction accuracy and success achieved by the individual models on their own. The scientific achievement of this study is that, by combining ML models with a suitable set of GECFs, data describing extant gullies, RS data, and GIS, one can produce reliably accurate GESMs. These GESMs were achieved with a method that is easy to use and can provide valuable information for planners or managers to prevent or respond to gully-erosion problems. This methodology can be used to assess gully-erosion susceptibility in similar regions of the world, especially in arid and semi-arid environments.

Supplementary Materials: The following are available online at http://www.mdpi.com/1424-8220/20/2/335/s1, Table S1: Lithology of study area. 
Author Contributions: Methodology, A.A., B.P., D.T.B., T.B., and H.R.P.; formal analysis, A.A., and H.R.P., investigation, A.A., H.R.P., and D.T.B.; writing—original draft preparation, A.A.; writing—review and editing, B.P., T.B., D.T.B., H.R.P., J.P.T., and A.A. All authors have read and agreed to the published version of the manuscript.

Funding: This research was partly funded by the Austrian Science Fund (FWF) through the Doctoral College GIScience (DK W 1237-N23) at the University of Salzburg.

Conflicts of Interest: The authors declare no conflict of interest.

\section{References}

1. Keesstra, S.; Mol, G.; de Leeuw, J.; Okx, J.; de Cleen, M.; Visser, S. Soil-related sustainable development goals: Four concepts to make land degradation neutrality and restoration work. Land 2018, 7, 133. [CrossRef]

2. Arabameri, A.; Cerda, A.; Rodrigo-Comino, J.; Pradhan, B.; Sohrabi, M.; Blaschke, T.; Tien Bui, D. Proposing a Novel Predictive Technique for Gully Erosion Susceptibility Mapping in Arid and Semi-arid Regions (Iran). Remote Sens. 2019, 11, 2577. [CrossRef]

3. Arabameri, A.; Pradhan, B.; Rezaei, K.; Yamani, M.; Pourghasemi, H.R.; Lombardo, L. Spatial modelling of gully erosion using Evidential Belief Function, Logistic Regression and a new ensemble EBF-LR algorithm. Land Degrad. Dev. 2018, 29, 4035-4049. [CrossRef]

4. Arabameri, A.; Chen, W.; Lombardo, L.; Blaschke, T.; Tien Bui, D. Hybrid Computational Intelligence Models for Improvement Gully Erosion Assessment. Remote Sens. 2020, 12, 140. [CrossRef]

5. Conforti, M.; Aucelli, P.P.; Robustelli, G.; Scarciglia, F. Geomorphology and GIS analysis for mapping gully erosion susceptibility in the Turbolo stream catchment (Northern Calabria, Italy). Nat. Hazards 2011, 56, 881-898. [CrossRef]

6. Arabameri, A. Application of the Analytic Hierarchy Process (AHP) for locating fire stations: Case Study Maku City. Merit Res. J. Art Soc. Sci. Humanit. 2014, 2, 001-010.

7. Arabameri, A. Zoning Mashhad Watershed for Artificial Recharge of Underground Aquifers Using TOPSIS Model and GIS Technique. Global Journal of human-social science: B Geography, Geo-Sciences. Environ. Disaster Manag. 2014, 14, 45-53.

8. Arabameri, A.; Rezaei, K.; Cerda, A.; Conoscenti, C.; Kalantari, Z. A comparison of statistical methods and multi-criteria decision making to map flood hazard susceptibility in Northern Iran. Sci. Total Environ. 2019, 660, 443-458. [CrossRef]

9. Arabameri, A.; Rezaei, K.; Cerda, A.; Lombardo, L.; Rodrigo-Comino, J. GIS-based groundwater potential mapping in Shahroud plain, Iran. A comparison among statistical (bivariate and multivariate), data mining and MCDM approaches. Sci. Total Environ. 2019, 658, 160-177. [CrossRef]

10. Yamani, M.; Arabameri, A. Comparison and evaluation of three methods of multi attribute decision making methods in choosing the best plant species for environmental management (Case study: Chah Jam Erg). Nat. Environ. Chang. 2015, 1, 49-62.

11. Rahmati, O.; Tahmasebipour, N.; Haghizadeh, A.; Pourghasemi, H.R.; Feizizadeh, B. Evaluating the influence of geo-environmental factors on gully erosion in a semi-arid region of Iran: An integrated framework. Sci. Total Environ. 2017, 579, 913-927. [CrossRef] [PubMed]

12. Meliho, M.; Khattabi, A.; Mhammdi, N. A GIS-based approach for gully erosion susceptibility modelling using bivariate statistics methods in the Ourika watershed, Morocco. Environ. Earth Sci. 2018, 77, 655. [CrossRef]

13. Zabihi, M.; Mirchooli, F.; Motevalli, A.; Darvishan, A.K.; Pourghasemi, H.R.; Zakeri, M.A.; Sadighi, F. Spatial modelling of gully erosion in Mazandaran Province, northern Iran. Catena 2018, 161, 1-13. [CrossRef]

14. Hosseinalizadeh, M.; Kariminejad, N.; Rahmati, O.; Keesstra, S.; Alinejad, M.; Behbahani, A.M. How can statistical and artificial intelligence approaches predict piping erosion susceptibility? Sci. Total Environ. 2019, 646, 1554-1566. [CrossRef] [PubMed]

15. Dube, F.; Nhapi, I.; Murwira, A.; Gumindoga, W.; Goldin, J.; Mashauri, D.A. Potential of weight of evidence modelling for gully erosion hazard assessment in Mbire District-Zimbabwe. Phys. Chem. Earth 2014, 67, 145-152. [CrossRef]

16. Kornejady, A.; Heidari, K.; Nakhavali, M. Assessment of landslide susceptibility, semi-quantitative risk and management in the Ilam dam basin, Ilam. Iran. Environ. Resour. Res. 2015, 3, 85-109. 
17. Azareh, A.; Rahmati, O.; Rafiei-Sardooi, E.; Sankey, J.B.; Lee, S.; Shahabi, H.; BinAhmad, B. Modelling gully-erosion susceptibility in a semi-arid region, Iran: Investigation of applicability of certainty factor and maximum entropy models. Sci. Total Environ. 2019, 655, 684-696. [CrossRef]

18. Amiri, M.; Pourghasemi, H.R.; Ghanbarian, G.A.; Afzali, S.F. Assessment of the importance of gully erosion effective factors using Boruta algorithm and its spatial modeling and mapping using three machine learning algorithms. Geoderma 2019, 340, 55-69. [CrossRef]

19. Rahmati, O.; Tahmasebipour, N.; Haghizadeh, A.; Pourghasemi, H.R.; Feizizadeh, B. Evaluation of different machine learning models for predicting and mapping the susceptibility of gully erosion. Geomorphology 2017, 298, 118-137. [CrossRef]

20. Gómez-Gutiérrez, Á.; Conoscenti, C.; Angileri, S.E.; Rotigliano, E.; Schnabel, S. Using topographical attributes to evaluate gully erosion proneness (susceptibility) in two mediterranean basins: Advantages and limitations. Natural Hazards 2015, 79, 291-314. [CrossRef]

21. Hosseinalizadeh, M.; Kariminejad, N.; Chen, W.; Pourghasemi, H.R.; Alinejad, M.; Behbahani, A.M.; Tiefenbacher, J.P. Gully headcut susceptibility modeling using functional trees, naïve Bayes tree, and random forest models. Geoderma 2019, 342, 1-11. [CrossRef]

22. Arabameri, A.; Pourghasemi, H.R. Spatial Modeling of Gully Erosion Using Linear and Quadratic Discriminant Analyses in GIS and R. In Spatial Modeling in GIS and R for Earth and Environmental Sciences, 1st ed.; Pourghasemi, H.R., Gokceoglu, C., Eds.; Elsevier Publication: Amsterdam, The Netherlands, 2019; 796p.

23. Hosseinalizadeh, M.; Kariminejad, N.; Chen, W.; Pourghasemi, H.R.; Alinejad, M.; Behbahani, A.M.; Tiefenbacher, J.P. Spatial modelling of gully headcuts using UAV data and four best-first decision classifier ensembles (BFTree, Bag-BFTree, RS-BFTree, and RF-BFTree). Geomorphology 2019, 329, 184-193. [CrossRef]

24. Pourghasemi, H.R.; Yousefi, S.; Kornejady, A.; Cerdà, A. Performance assessment of individual and ensemble data-mining techniques for gully erosion modeling. Sci. Total Environ. 2017, 609, 764-775. [CrossRef] [PubMed]

25. Gayen, A.; Pourghasemi, H.R. Spatial Modeling of Gully Erosion: A New Ensemble of CART and GLM Data-Mining Algorithms. In Spatial Modeling in GIS and $R$ for Earth and Environmental Science; Elsevier: Amsterdam, The Netherlands, 2019; pp. 653-669.

26. Gayen, A.; Pourghasemi, H.R.; Saha, S.; Keesstra, S.; Bai, S. Gully erosion susceptibility assessment and management of hazard-prone areas in India using different machine learning algorithms. Sci. Total Environ. 2019, 668, 124-138. [CrossRef]

27. Arabameri, A.; Pradhan, B.; Rezaei, K.; Conoscenti, C. Gully erosion susceptibility mapping using GIS-based multi-criteria decision analysis techniques. Catena 2019, 180, 282-297. [CrossRef]

28. Regmi, A.D.; Devkota, K.C.; Yoshida, K.; Pradhan, B.; Pourghasemi, H.R.; Kumamoto, T.; Akgun, A. Application of frequency ratio, statistical index, and weights-of-evidence models and their comparison in landslide susceptibility mapping in Central Nepal Himalaya. Arab. J. Geosci. 2014, 7, 725-742. [CrossRef]

29. Van Westen, C.J. Statistical landslide hazard analysis. ILWIS 1997, 2, 73-84.

30. Chen, W.; Panahi, M.; Khosravi, K.; Pourghasemi, H.R.; Rezaie, F.; Parvinnezhad, D. Spatial prediction of groundwater potentiality using ANFIS ensembled with teaching-learning-based and biogeography-based optimization. J. Hydrol. 2019, 572, 435-448. [CrossRef]

31. Chen, W.; Pradhan, B.; Li, S.; Shahabi, H.; Rizeei, H.M.; Hou, E.; Wang, S. Novel Hybrid Integration Approach of Bagging-Based Fisher's Linear Discriminant Function for Groundwater Potential Analysis. Nat. Resour. Res. 2019, 28, 1239-1258. [CrossRef]

32. Bui, D.T.; Ho, T.C.; Pradhan, B.; Pham, B.T.; Nhu, V.H.; Revhaug, I. GIS-based modeling of rainfall-induced landslides using data mining-based functional trees classifier with AdaBoost, Bagging, and MultiBoost ensemble frameworks. Environ. Earth Sci. 2016, 75, 1101.

33. Water Resources Company of Semnan (WRCS). Precipitation and Temperature Reports. Available online: http://www.Semnanrw.ir/index.aspx?siteid=1\&fkeyid=\&siteid=1\&pageid=183 (accessed on 21 August 2018).

34. Geological Survey Department of Iran (GSDI). 1997. Available online: http://www.gsi.ir/Main/Lang_en/ index.html (accessed on 21 August 2018).

35. USDA. Keys to soil taxonomy, USDA (United States Department of Agriculture), Soil Survey Staff, 10th ed.; Natural Resources Conservation Service: Washington, DC, USA, 2006; p. 333. 
36. Arabameri, A.; Chen, W.; Loche, M.; Zhao, X.; Li, Y.; Lombardo, L.; Cerda, A.; Pradhan, B.; Bui, D.T. Comparison of machine learning models for gully erosion susceptibility mapping. Geosci. Front. 2019, in press. [CrossRef]

37. Ghorbani Nejad, S.; Falah, F.; Daneshfar, M.; Haghizadeh, A.; Rahmati, O. Delineation of groundwater potential zones using remote sensing and GIS-based data-driven models. Geocarto Int. 2016, 32, 167-187. [CrossRef]

38. Claps, P.; Fiorentino, M.; Oliveto, G. Informational entropy of fractal river networks. J. Hydrol. 1994, 187, 145-156. [CrossRef]

39. Althuwaynee, O.F.; Pradhan, B.; Park, H.J.; Lee, J.H. A novel ensemble bivariate statistical evidential belief function with knowledge-based analytical hierarchy process and multivariate statistical logistic regression for landslide susceptibility mapping. Catena 2014, 114, 21-36. [CrossRef]

40. Oh, H.J.; Pradhan, B. Application of a neuro-fuzzy model to landslide-susceptibility mapping for shallow landslides in a tropical hilly area. Comput. Geosci. 2011, 37, 1264-1276. [CrossRef]

41. Moore, I.D.; Grayson, R.B.; Ladson, A.R. Digital terrain modelling: A review of hydrological, geomorphological, and biological applications. Hydrol. Process 1991, 5, 3-30. [CrossRef]

42. De Reu, J.; Bourgeois, J.; Bats, M.; Zwertvaegher, A.; Gelorini, V.; De Smedt, P.; Chu, W.; Antrop, M.; De Maeyer, P.; Finke, P.; et al. Application of the topographic position index to heterogeneous landscapes. Geomorphology 2013, 186, 39-49. [CrossRef]

43. Stotle, J.; Liu, B.; Ritsema, C.J.; Van Den Elsen, H.G.M.; Hessel, R. Modeling water flow and sediment processes in a small gully system on the Loess Plateau in China. Catena 2003, 54, 117-130.

44. Zinck, J.A.; Lópezb, J.; Metternichtc, G.I.; Shresthaa, D.P.; Vázquez-Selemd, L. Mapping and modelling mass movements and gullies in mountainous areas using remote sensing and GIS techniques. Int. J. Appl. Earth Obs. 2001, 3, 43-53. [CrossRef]

45. Zakerinejad, R.; Maerker, M. An integrated assessment of soil erosion dynamics with special emphasis on gully erosion in the Mazayjan basin, southwestern Iran. Nat. Hazards 2015, 79, S25-S50. [CrossRef]

46. Choi, Y.; Park, H.; Sunwoo, C. Flood and gully erosion problems at the Pasir open pit coal mine, Indonesia: A case study of the hydrology using GIS. Bull. Eng. Geol. Environ. 2008, 67, 251-258. [CrossRef]

47. Nyssen, J.; Poesen, J.; Moeyersons, J.; Luyten, E.; Veyret Picot, M.; Deckers, J.; Mitiku, H.; Govers, G. Impact of road building on gully erosion risk, a case study from the northern Ethiopian highlands. Earth Surf. Process. Landf. 2002, 27, 1267-1283. [CrossRef]

48. Arabameri, A.; Pradhan, B.; Rezaei, K. Spatial prediction of gully erosion using ALOS PALSAR data and ensemble bivariate and data mining models. Geosci. J. 2019, 23, 669-686. [CrossRef]

49. Lucà, F.; Conforti, M.; Robustelli, G. Comparison of GIS-based gullying susceptibility mapping using bivariate and multivariate statistics: Northern Calabria, South Italy. Geomorphology 2011, 134, 297-308. [CrossRef]

50. Arabameri, A.; Cerda, A.; Tiefenbacher, J.P. Spatial pattern analysis and prediction of gully erosion using novel hybrid model of entropy-weight of evidence. Water 2019, 11, 1129. [CrossRef]

51. Rahmati, O.; Haghizadeh, A.; Pourghasemi, H.R.; Noormohamadi, F. Gully erosion susceptibility mapping: The role of GIS based bivariate statistical models and their comparison. Nat. Hazards 2016, 82, 1231-1258. [CrossRef]

52. Arabameri, A.; Pradhan, B.; Rezaei, K. Gully erosion zonation mapping using integrated geographically weighted regression with certainty factor and random forest models in GIS. J. Environ. Manag. 2019, 232, 928-942. [CrossRef]

53. Hong, H.; Kornejady, A.; Soltani, A.; Termeh, S.V.R.; Liu, J.; Zhu, A.X.; Hesar, A.Y.; Ahmad, B.B.; Wang, Y.C. Landslide susceptibility assessment in the Anfu County, China: Comparing different statistical and probabilistic models considering the new topo-hydrological factor (HAND). Earth Sci. Inf. 2018, 11, 605-622. [CrossRef]

54. Mandal, S.; Mandal, K. Bivariate statistical index for landslide susceptibility mapping in the Rorachu river basin of eastern Sikkim Himalaya, India. Spat. Inf. Res. 2018, 26, 59-75. [CrossRef]

55. Nicu, I.C. Application of analytic hierarchy process, frequency ratio, and statistical index to landslide susceptibility: An approach to endangered cultural heritage. Environ. Earth Sci. 2018, 77, 79. [CrossRef] 
56. Aditian, A.; Kubota, T.; Shinohara, Y. Comparison of GIS-based landslide susceptibility models using frequency ratio, logistic regression, and artificial neural network in a tertiary region of Ambon, Indonesia. Geomorphology 2018, 318, 101-111. [CrossRef]

57. Breiman, L. Random Forests; Statistics Department, University of California: Berkeley, CA USA, 2011.

58. Cutler, D.R.; Edwards, T.C.; Beard, K.H.; Cutler, A.; Hess, K.T.; Gibson, J.; Lawler, J.J. Random forests for classification in ecology. Ecology 2007, 88, 2783-2792. [CrossRef] [PubMed]

59. Breiman, L.; Cutler, A. Breiman and Cutler's Random Forests for Classification and Regression, 1st ed.; 2018. Available online: https://www.stat.berkeley.edu/ \{\}breiman/RandomForests/ (accessed on 25 August 2018).

60. Pourghasemi, H.R.; Kerle, N. Random forests and evidential belief function-based landslide susceptibility assessment in Western Mazandaran Province, Iran. Environ. Earth Sci. 2016, 75, 185. [CrossRef]

61. Woodbury, A.; Render, F.; Ulrych, T. Practical probabilistic groundwater modeling. Groundwater 1995, 33, 532-538. [CrossRef]

62. Phillips, S.; Anderson, R.; Schapire, R. Maximum entropy modelling of species geo- graphic distributions. Ecol. Model. 2006, 190, 231-259. [CrossRef]

63. Harremoës, P.; Topsøe, F. Maximum entropy fundamentals. Entropy 2001, 3, 191-226. [CrossRef]

64. Ahmedou, A.; Marion, J.-M.; Pumo, B. Generalized linear model with functional predictors and their derivatives. J. Multivar. Anal. 2016, 146, 313-324. [CrossRef]

65. Naimi, B.; Araújo, M.B. sdm: A reproducible and extensible R platform for species distribution modelling. Ecography 2016, 39, 368375. [CrossRef]

66. Ramsay, J.; Dalzell, C.J. Some tools for functional data analysis (with discussion). J. R. Statist. Soc. B 1991, 53, 539-572.

67. Seifi Majdar, R.; Ghassemian, H. Spectral-spatial classification of hyperspectral images using functional data analysis. Remote Sens. Lett. 2017, 8, 488-497. [CrossRef]

68. Hwang, C.L.; Yoon, N. Multiple Attributes Decision Making Methods and Application, 1st ed.; Springer: Berlin, Germany, 1981. [CrossRef]

69. Olson, D.L. Comparison of weights in TOPSIS models. Math. Comput. Model 2004, 40, 21-727. [CrossRef]

70. Pourghasemi, H.R.; Rossi, M. Landslide susceptibility modeling in a landslide prone area in Mazandarn Province, north of Iran: A comparison between GLM, GAM, MARS, and M-AHP methods. Theor. Appl. Climatol. 2017, 130, 609-633. [CrossRef]

71. Cama, M.; Lombardo, L.; Conoscenti, C.; Rotigliano, E. Improving transferability strategies for debris flow susceptibility assessment: Application to the Saponara and Itala catchments (Messina, Italy). Geomorphology 2017, 288, 52-65. [CrossRef]

72. Arabameri, A.; Pradhan, B.; Lombardo, L. Comparative assessment using boosted regression trees, binary logistic regression, frequency ratio and numerical risk factor for gully erosion susceptibility modelling. Catena 2019, 183, 104223. [CrossRef]

73. Razavizadeh, S.; Solaimani, K.; Massironi, M.; Kavian, A. Mapping landslide susceptibility with frequency ratio, statistical index, and weights of evidence models: A case study in Northern Iran. Environ. Earth Sci. 2017, 76, 499. [CrossRef]

74. Liu, J.; Duan, Z. Quantitative Assessment of Landslide Susceptibility Comparing Statistical Index, Index of Entropy, andWeights of Evidence in the Shangnan Area, China. Entropy 2018, 20, 868. [CrossRef]

75. Arabameri, A.; Abbasi, S.; Eftekhari, S.M.; Amouniya, H. Selection the Most Suitable Species type for stabiliting sand dunes in dealing with the spread of desertification for environmental sustainability using TOPSIS method (Case study: Chah Jam Erg in South of Haj Ali Gholi Playa in Central part of Semnan Province, Iran). Petroleum Geosci. 2014, 70, 23793-23798.

76. Arabameri, A.; Pourghasemi, H.R.; Cerda, A. Erodibility prioritization of sub-watersheds using morphometric parameters analysis and its mapping: A comparison among TOPSIS, VIKOR, SAW, and CF multi-criteria decision making models. Sci. Total Environ. 2017, 613-614, 1385-1400.

77. Beullens, J.; Van de Velde, D.; Nyssen, J. Impact of slope aspect on hydrological rain-fall and on the magnitude of rill erosion in Belgium and northern France. Catena 2014, 114, 129-139. [CrossRef]

78. Pelletier, J.D.; Barron-Gafford, G.A.; Breshears, D.D.; Brooks, P.D.; Chorover, J.; Durcik, M.; Wagner-Muns, I.M.; Guardiola, I.G.; Samaranayke, V.A.; Kayani, W.I. A Functional data analysis approach to traffic volume forecasting. IEEE Trans. Intell. Transp. Syst. 2018, 19, 878888. 
79. Agnesi, V.; Angileri, S.; Cappadonia, C.; Conoscenti, C.; Rotigliano, E. Multi-parametric GIS analysis to assess gully erosion susceptibility: A test in southern Sicily, Italy. Landf. Anal. 2011, 7, 15-20.

80. Harvey, A.M. The role of piping in the development of badlands and gully systems in south-east Spain. In Badland Geomorphology and Piping; Bryan, R., Yair, A., Eds.; Geobooks: Norwich, UK, 1982; pp. 317-335.

81. Valentin, C.; Poesen, J.; Li, Y. Gully erosion: Impacts, factors and control. Catena 2005, 63, 132-153. [CrossRef]

82. Arabameri, A.; Pradhan, B.; Pourghasemi, H.R.; Rezaei, K.; Kerle, N. Spatial Modelling of Gully Erosion Using GIS and R Programing: A Comparison among Three Data Mining Algorithms. Appl. Sci. 2018, 8, 1369. [CrossRef]

83. Conoscenti, C.; Angileri, S.; Cappadonia, C.; Rotigliano, E.; Agnesi, V.; Märker, M. Gully erosion susceptibility assessment by means of GIS-based logistic regression: A case of Sicily (Italy). Geomorphology 2014, 204, 399-411. [CrossRef]

84. Belayneh, L.; Bantider, A.; Moges, A. Road construction and gully development in Hadero Tunto-Durgi road project, Southern Ethopia. Ethiop. J. Environ. Stud. Manag. 2014, 7, 720-730. [CrossRef]

85. Shellberg, J.G.; Spencer, J.; Brooks, A.P.; Pietsch, T.J. Degradation of the Mitchell Riverfluvialmegafan by alluvial gully erosion increased by post-European land use change, Queensland, Australia. Geomorphology 2016, 266, 105-120. [CrossRef]

86. Nyssen, J.; Poesen, J.; Moeyersons, J.; Luyten, E.; Veyret-Picot, M.; Deckers, J.; Haile, M.; Svoray, T.; Markovitch, H. Catchment scale analysis of the effect of topography, tillage direction and unpaved roads on ephemeral gully incision. Earth Surf. Process Landf. 2009, 34, 1970-1984.

87. Cevik, E.; Topal, T. GIS-based landslide susceptibility mapping for a problematic segment of the natural gas pipeline, Hendek (Turkey). Environ. Geol. 2003, 44, 949-962. [CrossRef]

88. Arabameri, A.; Rezaei, K.; Pourghasemi, H.R.; Lee, S.; Yamani, M. GIS-based gully erosion susceptibility mapping: A comparison among three data-driven models and AHP knowledge-based technique. Environ. Earth Sci. 2018, 77, 628. [CrossRef]

89. Dickie, J.A.; Parsons, A.J. Eco-geomorphological processes within grasslands, shrub lands and badlands in the semi-arid Karoo, South Africa. Land Degrad. Dev. 2012, 23, 534-547. [CrossRef]

90. Zucca, C.; Canu, A.; Della Peruta, R. Effects of land use and landscape on spatial distribution and morphological features of gullies in an agropastoral area in Sardinia (Italy). Catena 2006, 68, 87-95. [CrossRef]

91. Arabameri, A.; Chen, W.; Blaschke, T.; Tiefenbacher, J.P.; Pradhan, B.; Tien Bui, D. Gully Head-Cut Distribution Modeling Using Machine Learning Methods-A Case Study of N.W. Iran. Water 2020, 12, 16. [CrossRef]

92. Zhang, G.S.; Chan, K.Y.; Oates, A.; Heenan, D.P.; Huang, G.B. Relationship between soil structure and runoff/soil loss after 24 years of conservation tillage. Soil Tillage Res. 2007, 92, 122-128. [CrossRef]

93. García-Ruiz, J.M. The effects of land uses on soil erosion in Spain: A review. Catena 2010, 81, 1-11. [CrossRef]

94. Poesen, J.; Nachtergaele, J.; Verstraeten, G.; Valentin, C. Gully erosion and environmental change: Importance and research needs. Catena 2003, 50, 91-133. [CrossRef]

95. Garosi, Y.; Sheklabadi, M.; Pourghasemi, H.R.; Besalatpour, A.A.; Conoscenti, C.; Van Oost, K. Comparison of differences in resolution and sources of controlling factors for gully erosion susceptibility mapping. Geoderma 2018, 330, 65-78. [CrossRef]

96. Kim, J.C.; Lee, S.; Jung, H.S.; Lee, S. Landslide susceptibility mapping using random forest and boosted tree models in Pyeong-Chang, Korea. Geocato Int. 2018, 33, 1000-1015. [CrossRef]

97. Kantardzic, M. Data Mining: Concepts, Models, Methods, and Algorithms, 2nd ed.; John Wiley \& Sons, Inc.: Hoboken, NJ, USA, 2004.

98. Lombardo, L.; Bachofer, F.; Cama, M.; Märker, M.; Rotigliano, E. Exploiting Maximum Entropy method and ASTER data for assessing debris flow and debris slide suscepti- bility for the Giampilieri catchment (north-eastern Sicily, Italy). Earth Surf. Process. Landf. 2016, 41, 1776-1789. [CrossRef]

99. Pandey, V.K.; Pourghasemi, H.R.; Sharma, M.C. Landslide susceptibilitymappingusing maximum entropy and support vector machine models along the Highway Corridor, Garhwal Himalaya. Geocarto Int. 2018. [CrossRef]

100. Siahkamari, S.; Haghizadeh, A.; Zeinivand, H.; Tahmasebipour, N.; Rahmati, O. Spatial prediction of flood-susceptible areas using frequency ratio and maximum en- tropy models. Geocarto Int. 2018, 33, 927-941. [CrossRef]

101. Tan, L.; Taniar, D. Adaptive estimated maximum-entropy distribution model. Inf. Sci. 2007, 177, 3110-3128. [CrossRef] 
102. Genuer, R.; Poggi, J.-M.; Tuleau-Malot, C.; Villa-Vialaneix, N. Random forests for big data. Big Data Res. 2017, 9, 28-46. [CrossRef]

103. Kornejady, A.; Pourghasemi, H.R.; Afzali, S.F. Presentation of RFFR New Ensemble Model for Landslide Susceptibility Assessment in Iran. In Landslides: Theory, Practice and Modelling. Advances in Natural and Technological Hazards Research; Pradhan, S., Vishal, V., Singh, T., Eds.; Springer: Cham, Switzerland, 2019; Volume 50.

(c) (2)

(C) 2020 by the authors. Licensee MDPI, Basel, Switzerland. This article is an open access article distributed under the terms and conditions of the Creative Commons Attribution (CC BY) license (http://creativecommons.org/licenses/by/4.0/). 